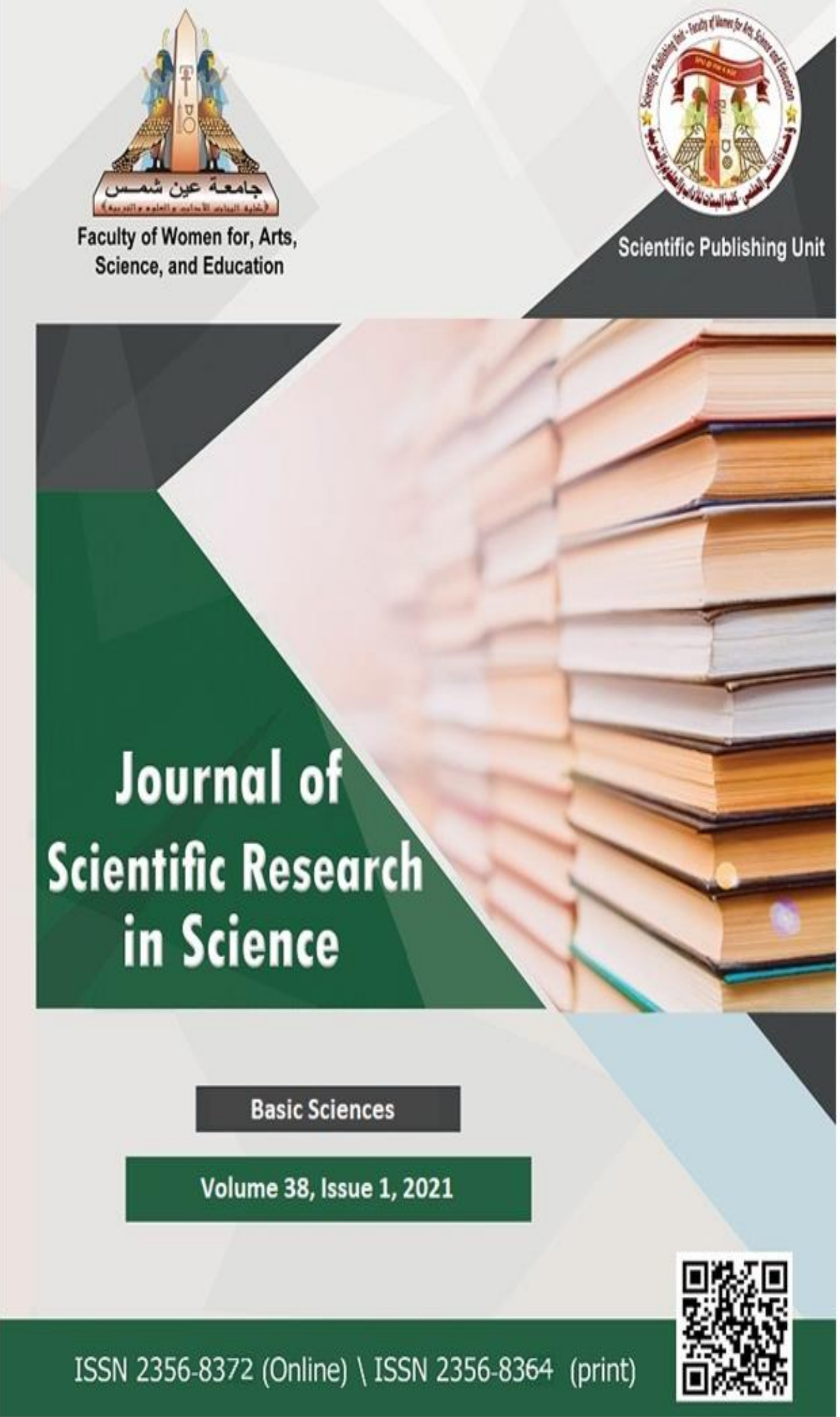




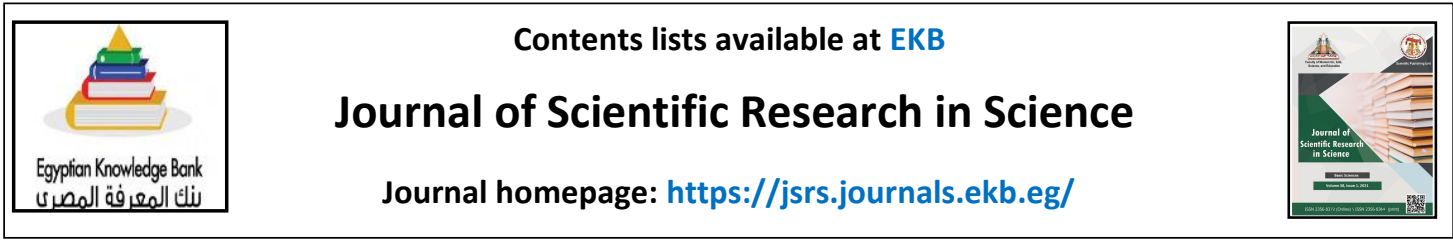

\title{
Effect of sulphate, chloride and elevated temperature on the properties of Egyptian slag binder
}

\author{
B.S. Ibrahim ${ }^{1, *}$, Essam kishar ${ }^{2}$, Mohamed Heikal ${ }^{3}$, S. Awad ${ }^{1}$ \\ ${ }^{1}$ Faculty of Engineering, Benha University, Benha, Egypt \\ ${ }^{2}$ Chemistry Department, Faculty of Women for Arts, Science and Education, Ain, \\ Shams University. \\ ${ }^{3}$ Chemistry Department, Faculty of Science, Benha University
}

\begin{abstract}
:
The present research aims to explain the physico-chemical and mechanical characteristics of alkali activated slag geopolymer binder (AASGB). Commercial sodium hydroxide ( $\mathrm{SH}$ ) and sodium silicate liquid (SSL) are utilized as an alkaline activator at different temperature namely $25^{\circ} \mathrm{C}$ and $65^{\circ} \mathrm{C}$. The hydration characteristics and physico-mechanical properties are illustrated through the determination of combined water contents $\mathrm{Wn}$ ), combined slag, total porosity (TP), compressive strength (CS), bulk density (BD) and XRD analysis as spectroscopic tools upto 180 days. The durability of the AASGB against aggressive ions (sulphate and chloride ions ) as well as effect of elevated temperatures upto $1000^{\circ} \mathrm{C}$ are studied. The activated binders are immersed under $5 \% \mathrm{MgSO}_{4}$ and/or $5 \% \mathrm{MgCl}_{2}$ solutions upto12 months. The data showed that the higher concentration of $\mathrm{SH}(1 \mathrm{~mol} / \mathrm{kg})$ at $65^{\circ} \mathrm{C}$ exhibited the highest resistance to elevated temperature upto $1000^{\circ} \mathrm{C}$ as well as given a high resistance against sulphate and chloride attack.
\end{abstract}

Keywords: Alkali Activated Slag Geopolymer Binder (AASGB), Fire resistance,

Sulphate and Chloride Attack, Compressive strength.

\section{Introduction:}

The manufacture of the Portland cement (PC) raises global greenhouse gas pollution during calcination of clinker in hydrocarbon-heated furnaces. To decreases $\mathrm{CO}_{2}$ emissions and save energy, large quantities of industrial wastes such as FA, GBFS and SF were used to manufacture of alkali-activated binders.

*Corresponding author: B.S. Ibrahim, Department of Mathematics, Faculty of Engineering, Benha University, Benha, Egypt.

E-mail: drbasmasobhi@yahoo.com 
Geopolymer or alkali binders are materials characterized by networks of inorganic molecules or chains. These binders have technical and ecological characteristics as compared with portland cement (PC), where the commercial usage of geopolymer concrete has increased in recent years [1]. The production of geopolymers request 30-60\% less energy and released $80 \%$ lower carbon dioxide $\left(\mathrm{CO}_{2}\right)$ into the atmosphere as compared with the Portland cement production [2].

Geopolymer is a class of an inorganic polymer binders formed by reacting alumina-rich and silica-rich solids in a high alkaline solution. The geopolymers could generate by using several industrial by-products. Geopolymerization depends on components, particle size, degree of crystallisation and distribution, kind of alkaliactivators, $\mathrm{pH}$, ratio of $\mathrm{Si} / \mathrm{Al}$, water/binder ratio, healing states (temperature, degree of moisture, healing or opening state) [3]. Geopolymerization proceeded in various steps, the first step of alkaline activation involved the disintegration of aluminate $\left(\mathrm{AlO}_{4}\right)$ and silicate $\left(\mathrm{SiO}_{4}\right)$ starting materials that are activated by alkali, resulting geopolymer gel as final yield. Hydrolysis occurred in the second step, the bond breaks to allow $\mathrm{AlO}_{4}$ and $\mathrm{SiO}_{4}$ tetrahedral units to react with each other so that, the polymeric geopolymer precursors produced. A poly-condensation occurred in the final level, where the geopolymer gel solidified and shaped three-dimensional alumino-silicate network [4].

Geopolymer used in various applications as fire-resistant, sealants, concrete, ceramics, etc. Geopolymers are environmentally sustainable because of their excellent functional, durability to elevated temperature and their smaller carbon footprint than PC. Qureshi and Ghosh [5] examined an improvement in compressive strength (CS) by raising the alkaline content to $10.41 \%$. Further raising in the alkaline material reduces the CS. Li et al., [6] showed the mechanical characteristic and the microstructure of the AAS exposed to temperature at $400-800^{\circ} \mathrm{C}$. He demonstrated that the decrease in the CS by $23.9 \%$ to $35 \%$ at $400{ }^{\circ} \mathrm{C}$. After exposure at $800{ }^{\circ} \mathrm{C}$, another decrease in CS was observed to $87.0 \%$ relative to the reference blend.

Sulphate and chloride ions enter in the deleterious reactions of cement causes the disintegration of $\mathrm{CH}$, sedimentation of sulfoaluminates, gypsum and chloroaluminates causing the expansion and softening of concrete $[7,8]$. The existence of magnesium ions $\left(\mathrm{Mg}^{2+}\right)$ as $\mathrm{MgSO}_{4}$ and/or $\mathrm{MgCl}_{2}$ share in a deformation of C-S-H 
by dissolution of $\mathrm{Ca}^{2+}$ ions to produce $\mathrm{CH}$ and $\mathrm{Mg}-\mathrm{S}-\mathrm{H}$, which followed by a decline in the CS [9-13].

The durability of AAS pastes and concretes demonstrated by [14-19], they showed that the AASGB is more durable binders in sulphate and acid resistant.

This study aims to explain the effect of various alkaline concentrations and cure at elevated thermally treated temperature on the hydration characteristics of GBFS geopolymer. The resistance of the activated binders to sulphat, chloride attack as well as elevated temperatures are also investigated.

\section{Materials and experimental procedures:}

\subsection{Materials:}

The utilized materials are granulated blast furnace slag (GBFS), SSL and SH. GBFS is stocked from Iron and Steel Company, Helwan, Egypt. The surface area determined from Blaine test of GBFS was $3570 \mathrm{~cm}^{2}$. The SEM of GBFS is given in Fig. (1). Chemical analysis of GBFS is present in Table (1)

Table 1: Chemical analysis of GBFS

\begin{tabular}{|c|c|c|c|c|c|c|c|c|c|c|}
\hline slag & $\mathrm{SiO}_{2}$ & $\mathrm{Al}_{2} \mathrm{O}_{3}$ & $\mathrm{Fe}_{2} \mathrm{O}_{3}$ & $\mathrm{CaO}$ & $\mathrm{MgO}$ & $\mathrm{SO}_{3}$ & $\mathrm{~K}_{2} \mathrm{O}$ & $\mathrm{Na}_{2} \mathrm{O}$ & L.O.I & Total \\
\hline oxide & 43.21 & 9.97 & 0.59 & 35.96 & 5.43 & 1.37 & 0.67 & 0.79 & 1.98 & 99.97 \\
\hline
\end{tabular}

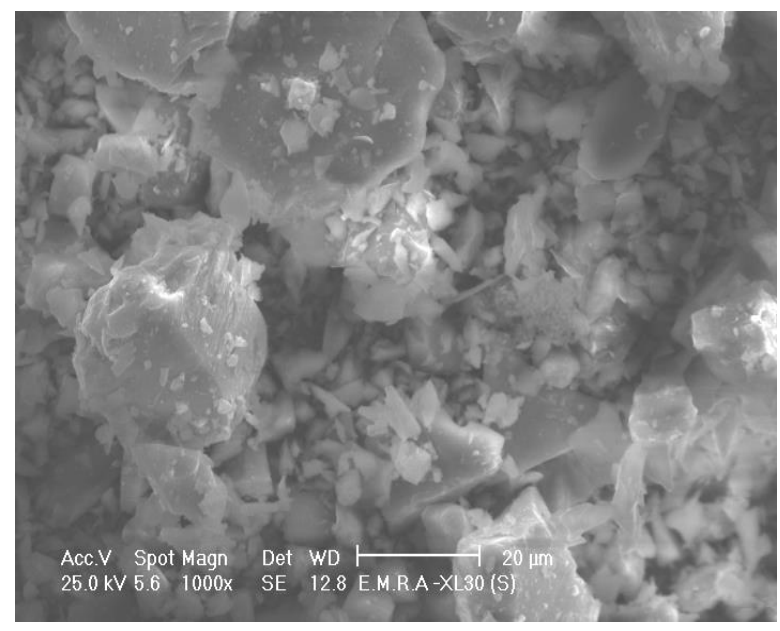

Figure 1: SEM of GBFS 


\subsection{Procedure:}

Various mixes are prepared as represented in Table (2). SSL and SH used as an alkaline activator in geopolymerization process, which dissolved in the mixing water as given in table (2). The binders are mixed in rotary mixer for 2 minutes. The prepared binders are molded in to $0.5 \times 0.5 \times 0.5$ inch stainless steel cubic moulds. In order to prepare a better compaction of the pastes the mould vibrated, to take out any air bubbles, then stored in $100 \% \mathrm{RH}$ after moulding at $25^{\circ} \mathrm{C}$ and $65^{\circ} \mathrm{C}$ for 3 days, then demoulded and then keep under water up to 180 days. For elevated thermally treated temperature, or firing resistance, the specimens cured at 28 days then dried at $100^{\circ} \mathrm{C}$ for one day, and then exposed to various elevated temperatures at $\left(200^{\circ} \mathrm{C}\right.$ upto $\left.1000^{\circ} \mathrm{C}\right)$ in an electric furnace at two hours, and then after thermally treated temperature cooled in off-closed furnace to reach room temperature.

For aggressive attack, the specimens are stored under water for 28 days (zero month), then subjected to $5 \% \mathrm{MgSO}_{4}$ or $5 \% \mathrm{MgCl}_{2}$ solution. The specimens are tested at 1,3,6 and 9 months.

Table. (2): Mix composition, designations and water/solid (W/S) ratio

\begin{tabular}{|c|c|c|c|c|c|}
\hline Mix No & GBFS & $\begin{array}{c}\mathrm{SSL}, \\
\mathrm{mol} / \mathrm{kg}\end{array}$ & $\begin{array}{r}\mathrm{SH}, \\
\mathrm{mol} / \mathrm{kg}\end{array}$ & $\begin{array}{l}\mathrm{W} / \mathrm{S} \\
\text { ratio }\end{array}$ & $\begin{array}{l}\text { cured } \\
\text { temperatures }\end{array}$ \\
\hline $\mathrm{S} 1$ & 100 & 0.75 & 0.5 & 28 & $25^{\circ} \mathrm{C}$ \\
\hline $\mathrm{S} 2$ & 100 & 0.75 & 0.5 & 28 & $65^{\circ} \mathrm{C}$ \\
\hline $\mathrm{S} 3$ & 100 & 0.75 & 1.0 & 13 & $25^{\circ} \mathrm{C}$ \\
\hline $\mathrm{S} 4$ & 100 & 0.75 & 1.0 & 13 & $65^{\circ} \mathrm{C}$ \\
\hline
\end{tabular}

\subsection{Methods of investigation:}

The binders are stopped using stopping solutions (1:1 acetone - methanol mixture), then dried at $70^{\circ} \mathrm{C}$ for one hour [20]. The physico-chemical and mechanical properties of geopolymer mixes are tested by determination; the compressive strength (CS) according to ASTM specification [21] by using $600 \mathrm{kN}$ capacity SEIDNER Riedinger compression-machine; combined water (Wn) and combined slag (CG) can 
be measured according to [7,22]. Bulk density and total porosity (TP) was calculated before the determination of CS [22]. Determination of total sulphate and chloride contents was determined according to [23]. XRD method used to determination the phase compositions of the formed hydrates. XRD technique is carried out on certain cement pastes to indicate the hydration products.

\section{Results and discussion:}

\subsection{Hydration characteristic of slag geopolymer:}

\subsubsection{Compressive strength:}

Figure (2) showed the $\mathrm{CS}$ of the activated mixes cured upto 180 days at $25^{\circ} \mathrm{C}$ and $65^{\circ} \mathrm{C}$. The results showed that the CS gradually increased with the time period for all hardened mixes, due to higher reactivity of AASGB and formation of successive amounts of calcium silicate hydrates $(\mathrm{CSH})$, calcium aluminium $(\mathrm{CAH})$ and sodiumaluminum-silicate gel (N,C) ASH through the activation process. These products precipitated in open pores, and creation of the compact-body. The data showed that the CS values improved with the increasing of the $\mathrm{Na}_{2} \mathrm{O}$ content and heat-treated temperatures to $65^{\circ} \mathrm{C}$. Mix S4 give the highest $\mathrm{CS}$ values at all curing period. The accumulation and precipitation of the large amount of (N,C) ASH gel improved the CS of AASGB binders [22,24]. Mix S4, which activated and thermally cured at $65^{\circ} \mathrm{C}$, has the highest CS values than other mixes. Mix S2 showed the resanable value of compressive strength of mix S3, especially at 3-28 days, then the CS of mix S3 increased upto 180 days due to the increasing of the alkaline activation with $1 \mathrm{~mol} / \mathrm{kg}$ of $\mathrm{Na}_{2} \mathrm{O}$. 


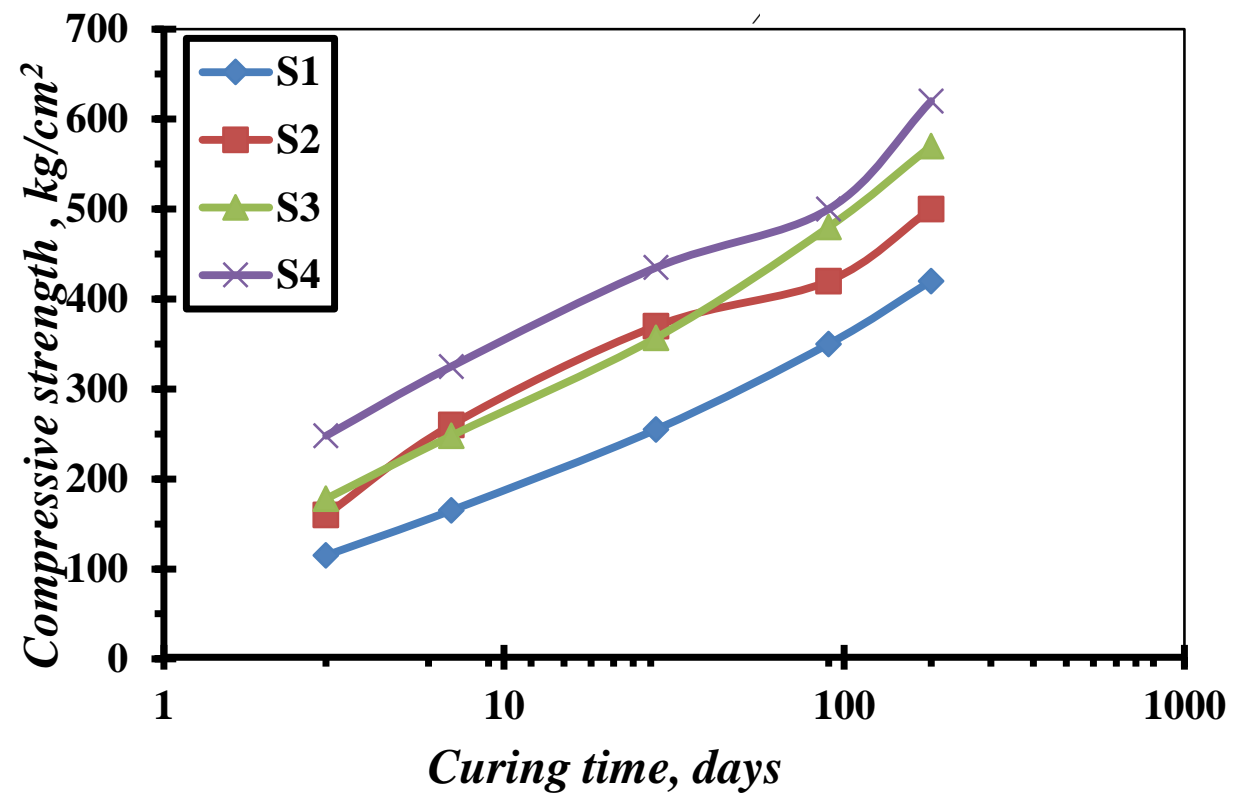

Fig. 2: Compressive strength (CS) of activated GBFS at 180 days.

\subsubsection{Chemically combined water contents:}

The chemically combined water (Wn) of activated mixes cured upto 180 days at $25^{\circ} \mathrm{C}$ and $65^{\circ} \mathrm{C}$ is graphically described in Fig. (3). The Wn content of all mixes improved with increasing the alkaline activation, hydration time, and thermally treated temperature to 180 days. This is due to the progress of geopolymer processes that is producing the geopolymrized products which precipitated in the empty vacant pores within the binder matrix. The results also observed that the Wn contents of AASGB enhanced as $\mathrm{Na}_{2} \mathrm{O}$ content increased from 0.5 to $1 \mathrm{~mol} / \mathrm{kg}$ as seen in mixes S2 and S4. Increasing alkaline activator concentration increased the rate of dissolution of GBFS, then increasing the production of CSH, CAH, (N,C)SAH geopolymer gel. The alkaline activator $\left(\mathrm{Na}_{2} \mathrm{O}: \mathrm{SiO}_{2}\right)$ facilitated the libration of $\mathrm{Ca}^{2+}, \mathrm{Si}^{4+}$ and $\mathrm{Al}^{3+}$ from GGBS grains, thereby enhancing GGBS hydrolytic degradation to produce more alkali-activated gel products $[\mathbf{2 5 , 2 2 ]}$. The data also revealed that the S2 and S4 mixes cured at $65{ }^{\circ} \mathrm{C}$ explained an improvement in the values of $\mathrm{Wn}$ relative to those of mixes cured at $25{ }^{\circ} \mathrm{C}$, due to geopolymerization reactions, synergetic activity of alkali concentration and higher curing temperature at $65^{\circ} \mathrm{C}$. 


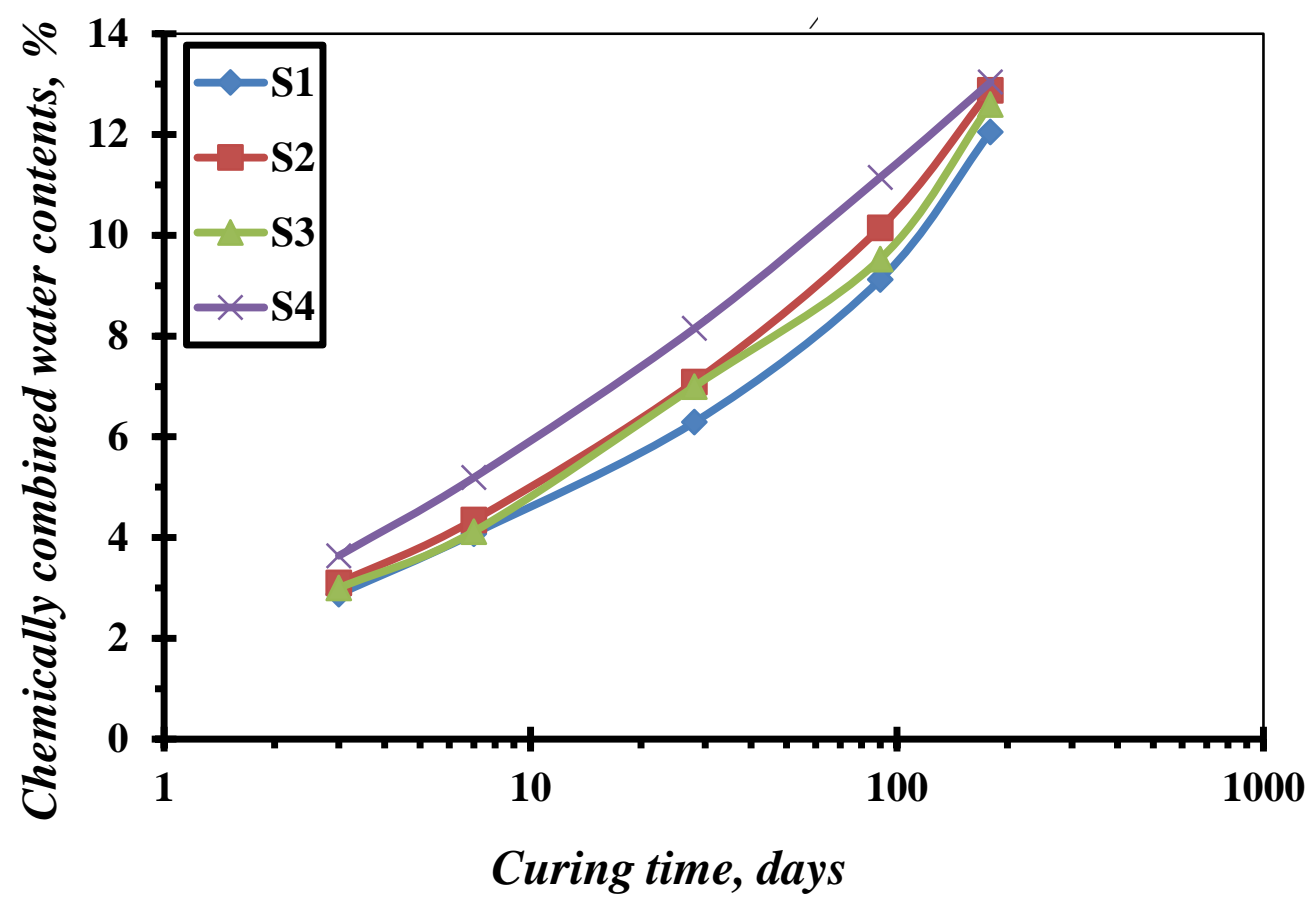

Fig. 3: Chemically combined water contents (Wn) of alkaline activated GBFS cured up to 180 days.

\subsubsection{Combined slag contents:}

The combined slag content (CG) of AASGB cured upto 180 days at $25^{\circ} \mathrm{C}$ and $65^{\circ} \mathrm{C}$ was plotted in Fig. (4). The data revealed that the combined slag content increased with the ages-period for all mixes, this is attributable to the production of excessive amount of CSH, CAH in addition to (N,C) ASH geopolymer gel. Increasing of $\mathrm{Na}_{2} \mathrm{O}$ alkali activated contents from 0.5 to $1 \mathrm{~mol} / \mathrm{kg}$ binder resulting an increasing of alkali-activated products. The combined slag of AASGB improved with the alkaliactivated content. The dissolved species of GGBS increased by increasing the $\mathrm{XNa}_{2} \mathrm{O}: \mathrm{SiO}_{2}$ content so a sharp increase in the combined slag observed. The combined slag of the mixes cured at $65^{\circ} \mathrm{C}$ were higher than the mixes cured at $25^{\circ} \mathrm{C}$. Mixes S2 and S4 at $65^{\circ} \mathrm{C}$ represented the highest combined slag values than other mixes. 


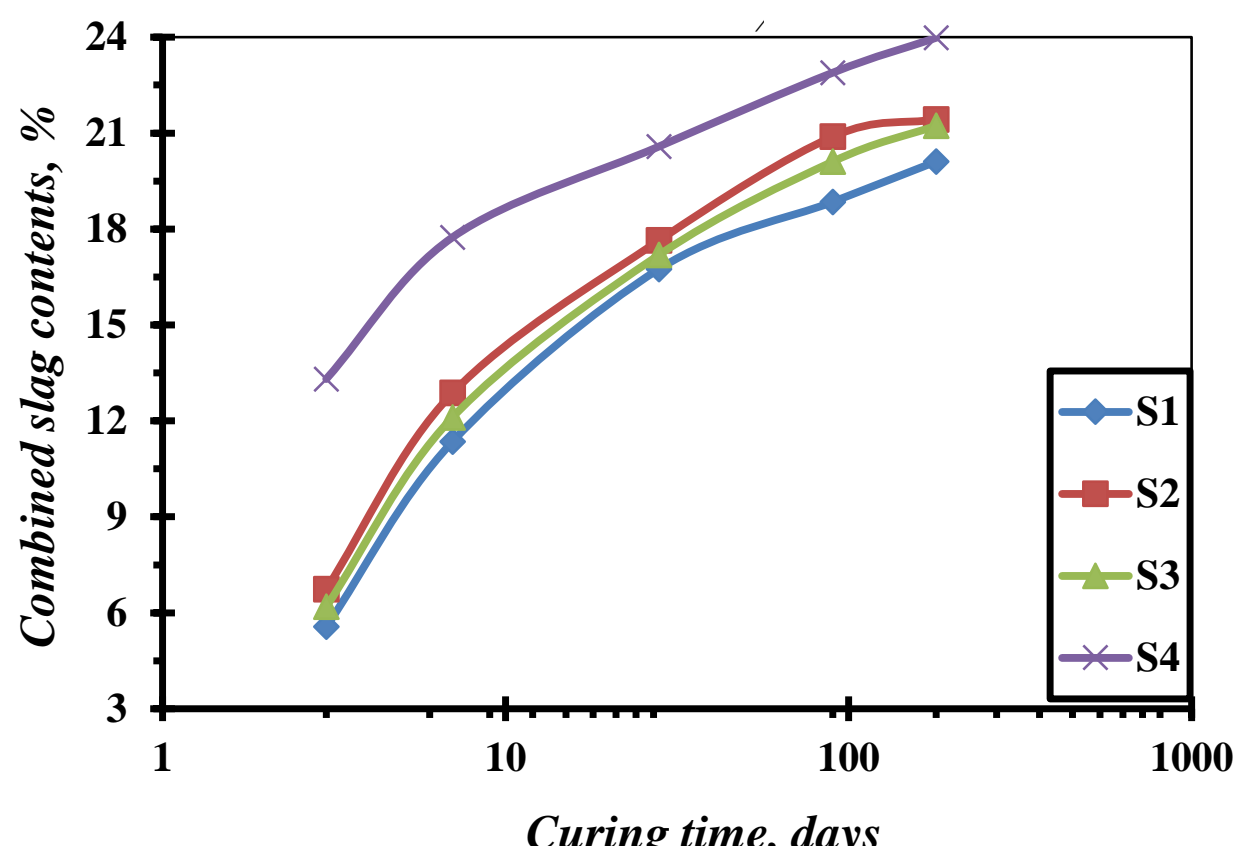

Fig. (4): Combined slag contents of alkali activated binder cured upto 180 days

\subsubsection{Bulk density and total porosity:}

Figure (5, A and B) shows the variation of bulk density (BD) and total porosity (TP) of the AAGSB cured at 180-days. The data showed that the values of the BD improved wherever the TP decreased with treatment temperatures and ages, this is accredited to the increase in the excessive of geopolymeric products with the alkaline activation contents. The addition of a chemical activator $\left(\mathrm{XNa}_{2} \mathrm{O}: \mathrm{SiO}_{2}\right)$ improved the concentration of $\left[\mathrm{SiO}_{4}\right]^{4-}$ and $\mathrm{AlO}_{4}{ }^{5-}$, that is intensified the production of AAGB [26]. As the curing temperature increased to $65^{\circ} \mathrm{C}$, the TP decreased as shown in the samples (S2 and S4). This is related to the formation of the $(\mathrm{N}, \mathrm{C}) \mathrm{ASH}$ gel which permit the formation of matrix structure with lower TP. Mix S4 gives lower values of TP. It can concluded that physico-mechanical properties, namely $\mathrm{CS}$ and $\mathrm{BD}$, are in good agreement with each other and represented in an increasing trend, while TP displayed a decreasing trend from 3180 days. 


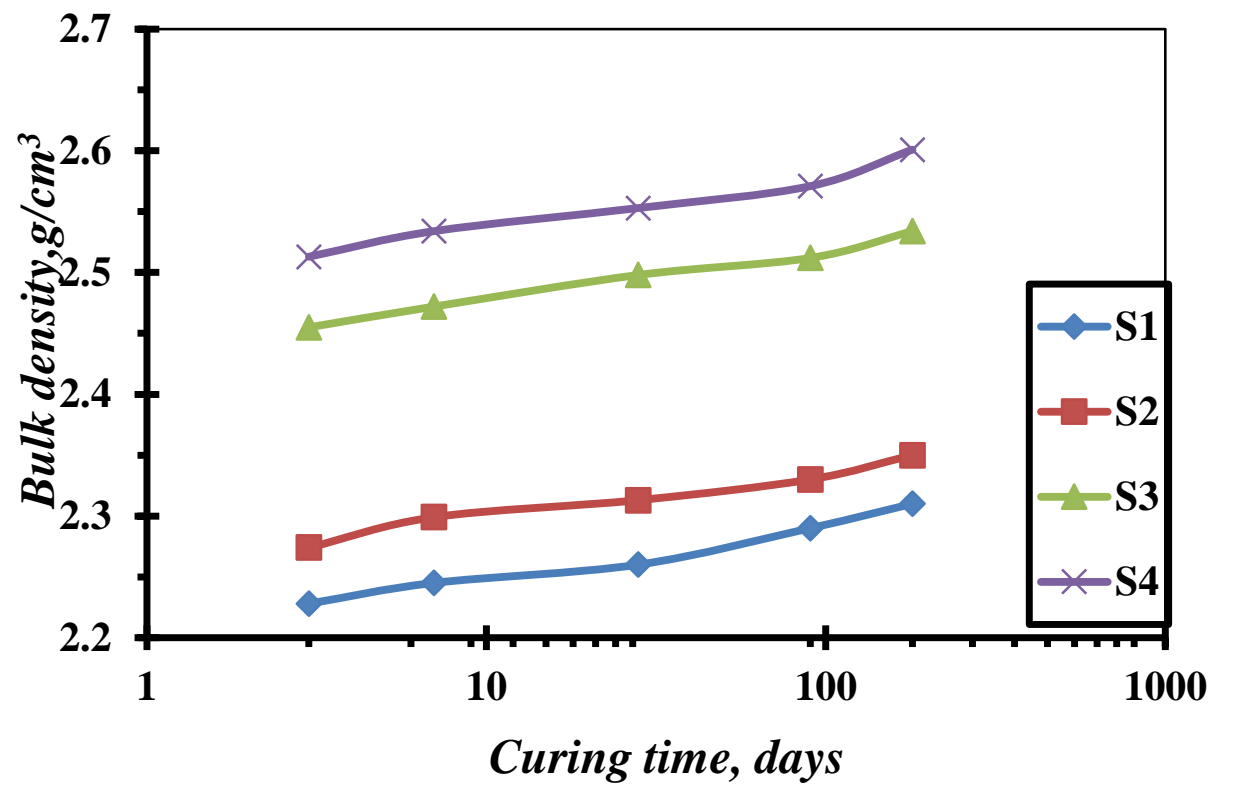

Fig. 5, A: Bulk density of alkaline activated GBFS upto 180 days.

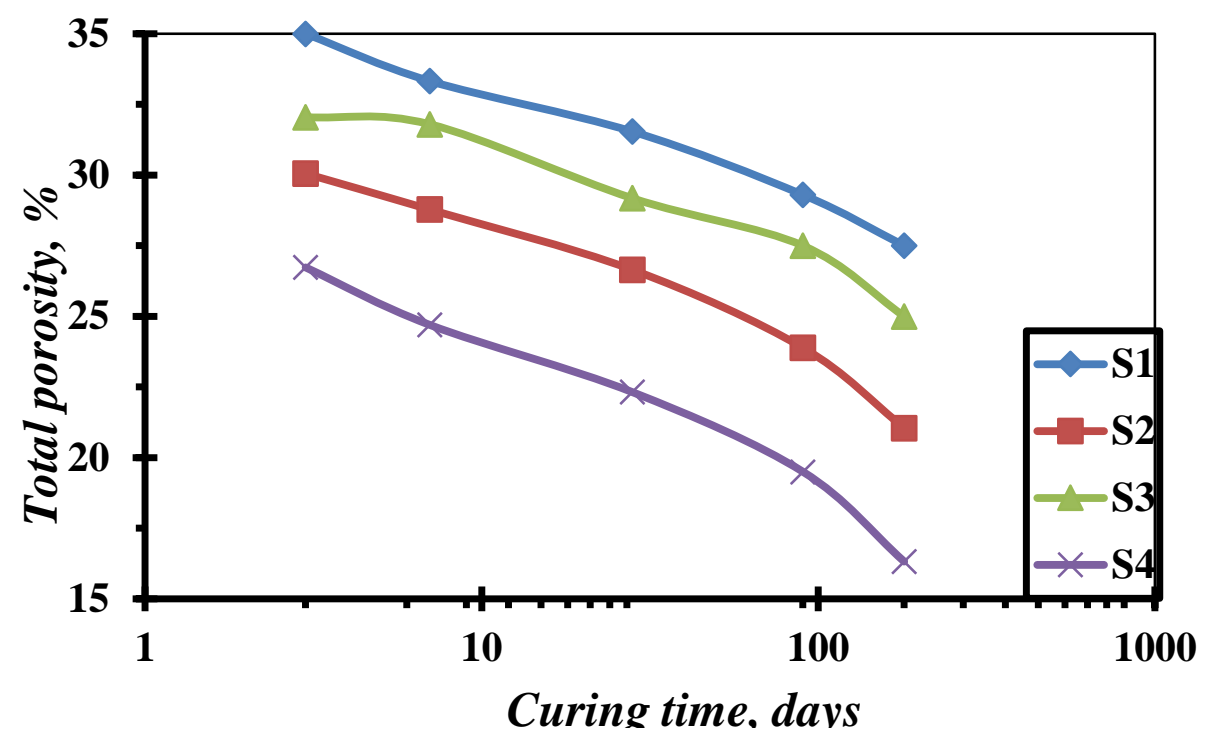

Fig. 5, B: Total porosity of alkaline activated GBFS binder upto 180 days.

\subsubsection{X-ray diffraction:}

Figure. (6, A and B), presented the XRD patterns of alkali-activated GBFS binders cured at 3,180 days at $25^{\circ} \mathrm{C}$ and $65^{\circ} \mathrm{C}$ with $\left(0.5: 0.75 \mathrm{Na}_{2} \mathrm{O}: \mathrm{SiO}_{2}\right)$ and (1.00:0.75 $\mathrm{Na}_{2} \mathrm{O}: \mathrm{SiO}_{2}$ ). XRD analyses are conducted on subjected mixes to examine the effect on the CS of AAGSB. The XRD of GBFS geopolymer as given in Fig. (6, $\mathrm{A}$ and $\mathrm{B}$ ) consisted of mainly amorphous and some crystalline phases such as $\mathrm{SiO}_{2}$, $\mathrm{CaCO}_{3}, \mathrm{CSH}$, gehlenite $\left(\mathrm{C}_{2} \mathrm{ASH}_{8}\right)$, wollastonite and tobermorite. The geopolymer 
pastes showed an improve in the mechanical characteristic as represented in Fig.2. The broad and diffuse peaks as represented in Figure. (6), including short-ordering structure or amorphous phases which existing in the AASG. Very small tobermorite and wollastonite $\left(\mathrm{C}_{2} \mathrm{ASH}_{8}\right)$ phases appeared in the XRD patterns, on the other side the $\mathrm{CaCO}_{3}$ phase give an enhanced at 180 days.

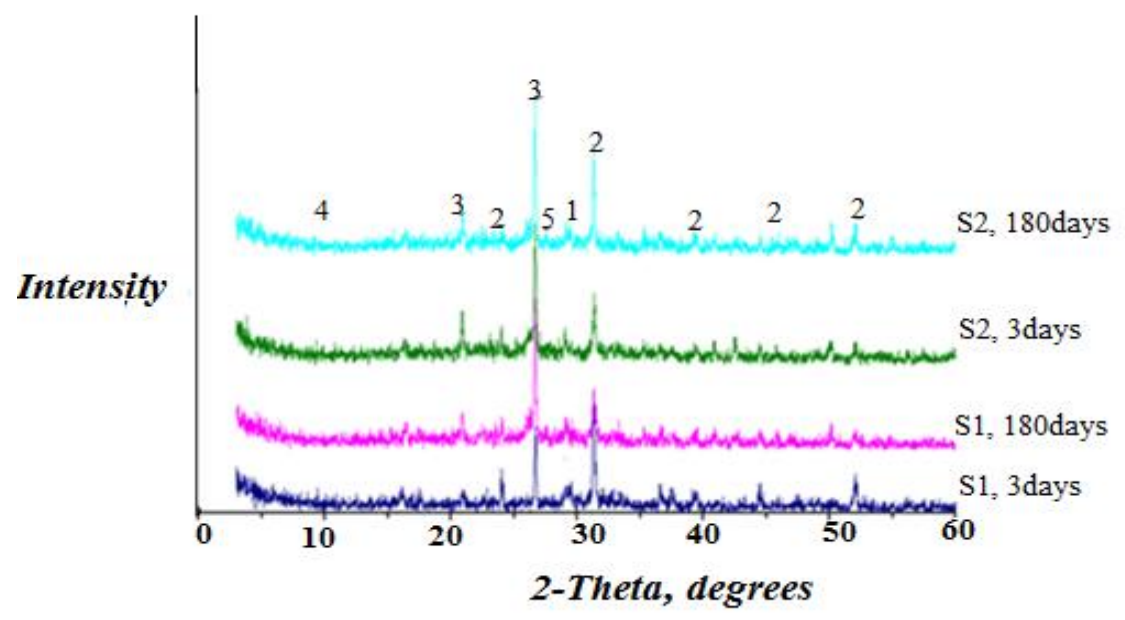

Fig. 6, A: XRD diffractograms of alkali activated GBFS binders cured upto 180 days at $25^{\circ} \mathrm{C}$ and $65^{\circ} \mathrm{C}(1=\mathrm{C}-\mathrm{S}-\mathrm{H} ; 2=$ gehlenite; $3=$ quartz; $4=$ tobermorite; $5=$ wollastonite

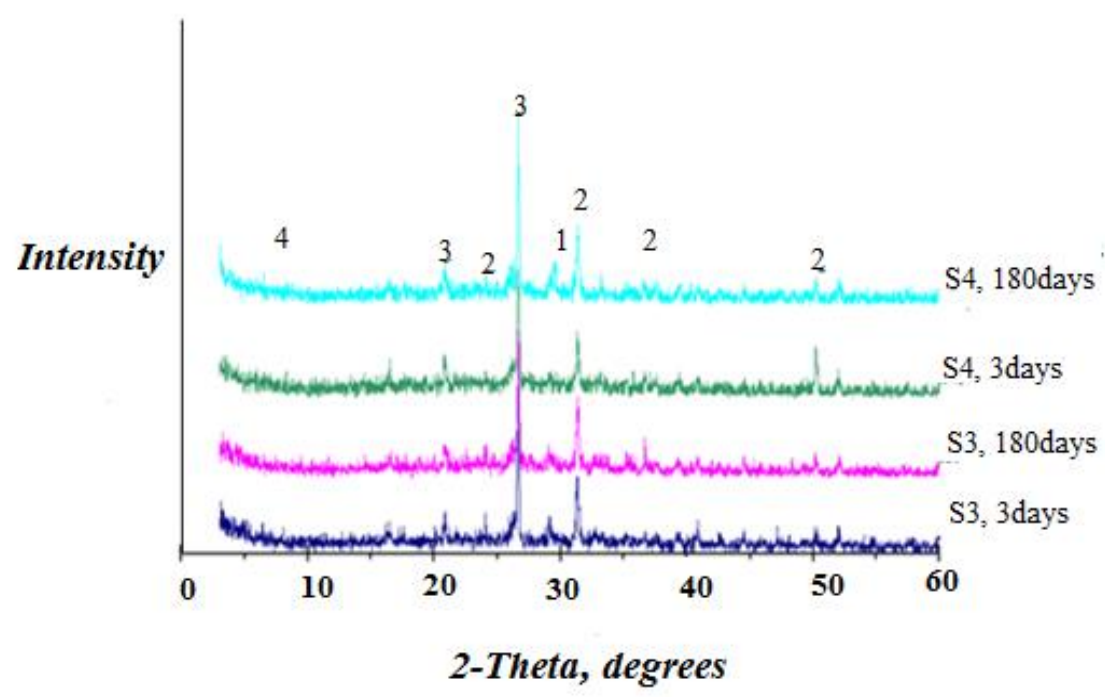

Fig. 6, B: XRD diffractograms of alkali activated GBFS binder cured upto 180 days at $25^{\circ} \mathrm{Cand} 65{ }^{\circ} \mathrm{C},(1=\mathrm{C}-\mathrm{S}-\mathrm{H} ; 2=$ gehlenite; $3=$ quartz; $4=$ tobermorite; $5=$ wollastonite. 


\subsection{Resistance to thermally treated temperatures:}

\subsubsection{Compressive strength:}

Compressive strength values of AAGSB mixes, exposed to various temperatures at $200,400,600,800$ and $1000{ }^{\circ} \mathrm{C}$ are given in Fig. (7). It is cleared that the $\mathrm{CS}$ of all specimens improved with the elevated temperature up to $400^{\circ} \mathrm{C}$, due to the acceleration effect on the geopolymerization process of alkaline activated slag particles producing self autoclaving effect, which increase the CS values [27]. Increase of the treatment temperature up to $600^{\circ} \mathrm{C}$, the $\mathrm{CS}$ values decreased, due to partial decomposition of the geopolymer network leading to the weaken of mechanical properties. Further increasing in the CS observed when the mixes subjected to the 800 and $1000^{\circ} \mathrm{C}$, this is attributed to the sintering process or solidstate reaction to produce a ceramic bond of mineral ingredients. Mix S4 exhibits the highest values of the CS at all thermally treated temperatures as compared to the other mixes. This is due to the presence of additional alumina-silicate networks during geopolymerisation process such as nepheline $\left[\mathrm{NaAlSiO}_{4}\right]$, gehlenite $\left[\mathrm{Ca} 2 \mathrm{Al}\left(\mathrm{AlSiO}_{7}\right)\right]$, analcime $\left[\mathrm{Na}\left(\mathrm{AlSi}_{2} \mathrm{O}_{6}\right) \cdot \mathrm{H}_{2} \mathrm{O}\right]$ and quartz as shown later in XRD pattern. The data showed that samples cured at $65{ }^{\circ} \mathrm{C}$ showed an increase in the CS than the samples cured at $25^{\circ} \mathrm{C}$.

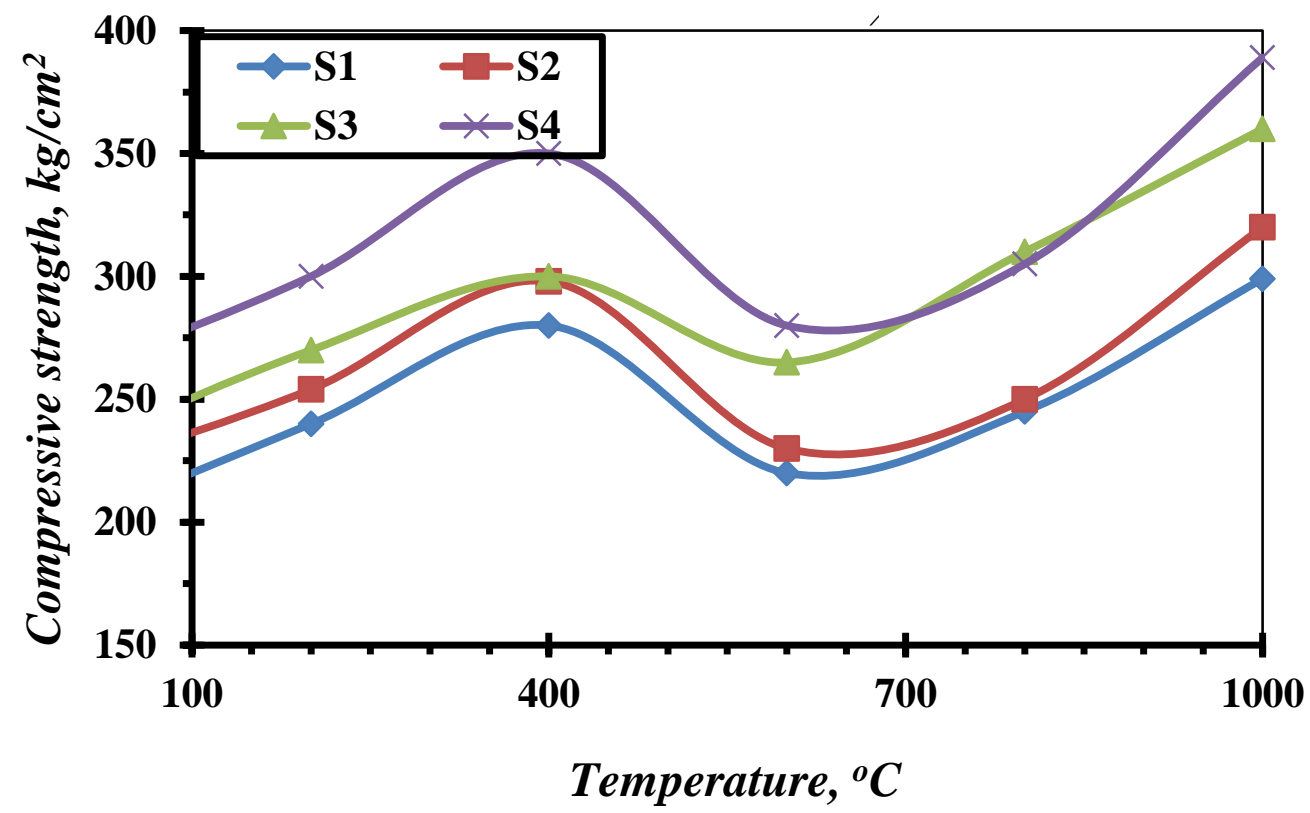

Fig. 7: Compressive strength values of activated binders at various firing temperature upto $1000{ }^{\circ} \mathrm{C}$. 


\subsubsection{Bulk density and Total porosity:}

The BD and TP of alkali activated GBFS mixes fired at different temperatures upto $1000^{\circ} \mathrm{C}$ are represented in Figure.(8, A and B). The data showed that the BD of activated binders enhanced by increasing the temperature upto $400^{\circ} \mathrm{C}$, when the samples exposed to further heating temperature at $600{ }^{\circ} \mathrm{C}$ the bulk density showed a small decrease. On the other hand after the specimens thermally treated upto 800 and $1000{ }^{\circ} \mathrm{C}$, an increase in the values of bulk density are observed again. From represented data, it is showed that the alkali activated,S4 mix exhibited the higher values of the bulk density and less values of the TP in comparison with the other mixes. Bulk density of GBFS based geopolymer which observed at $65{ }^{\circ} \mathrm{C}$ was more homogeneous than that of specimens at $25^{\circ} \mathrm{C}$. The production of more effective $(\mathrm{N}, \mathrm{C})$ ASH gel promoting the structure matrix with the lower values of the TP.

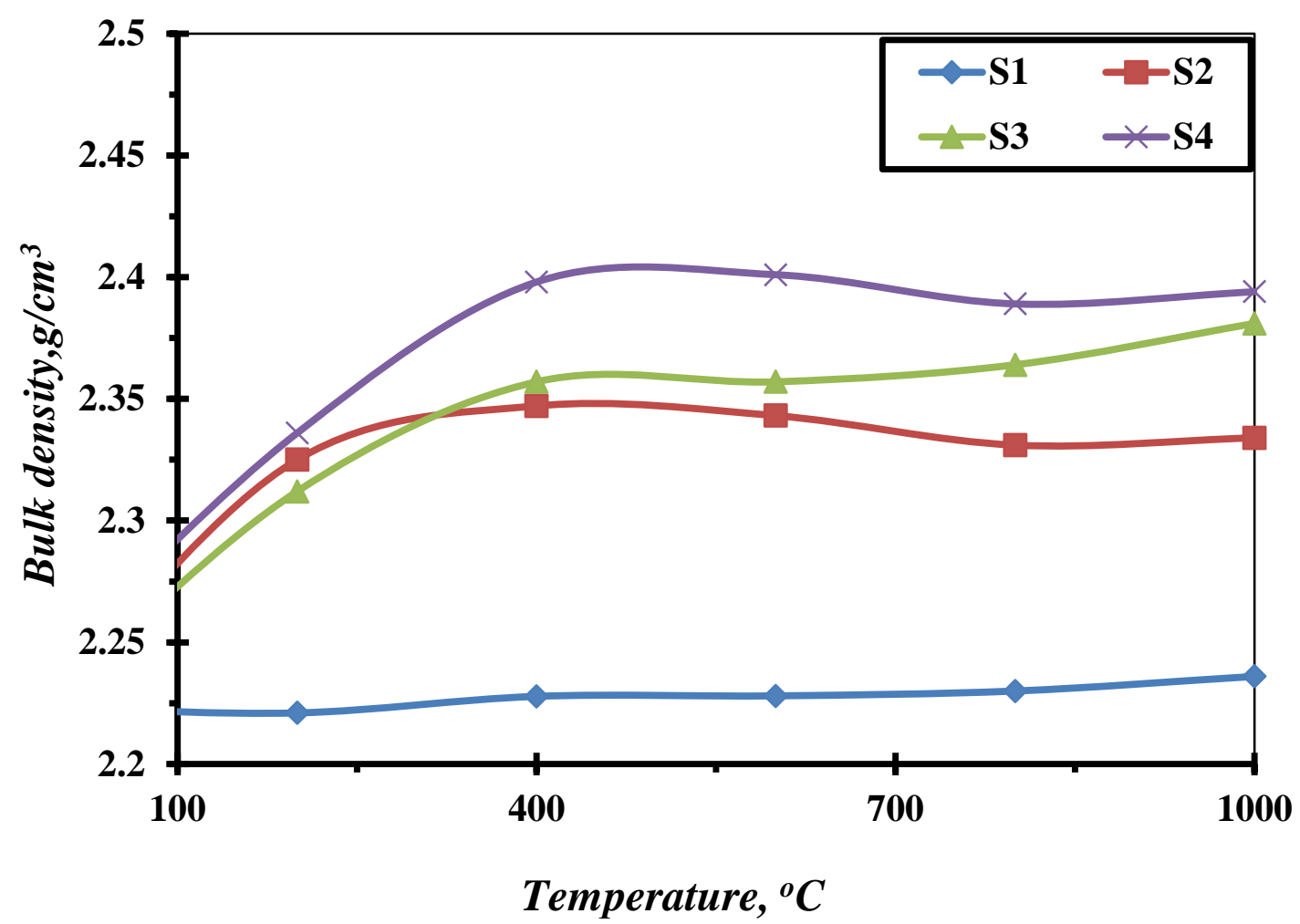

Fig. $(\mathbf{8}, \mathbf{A})$ : Bulk density values of activated mixes at various firing temperatures upto $1000^{\circ} \mathrm{C}$. 


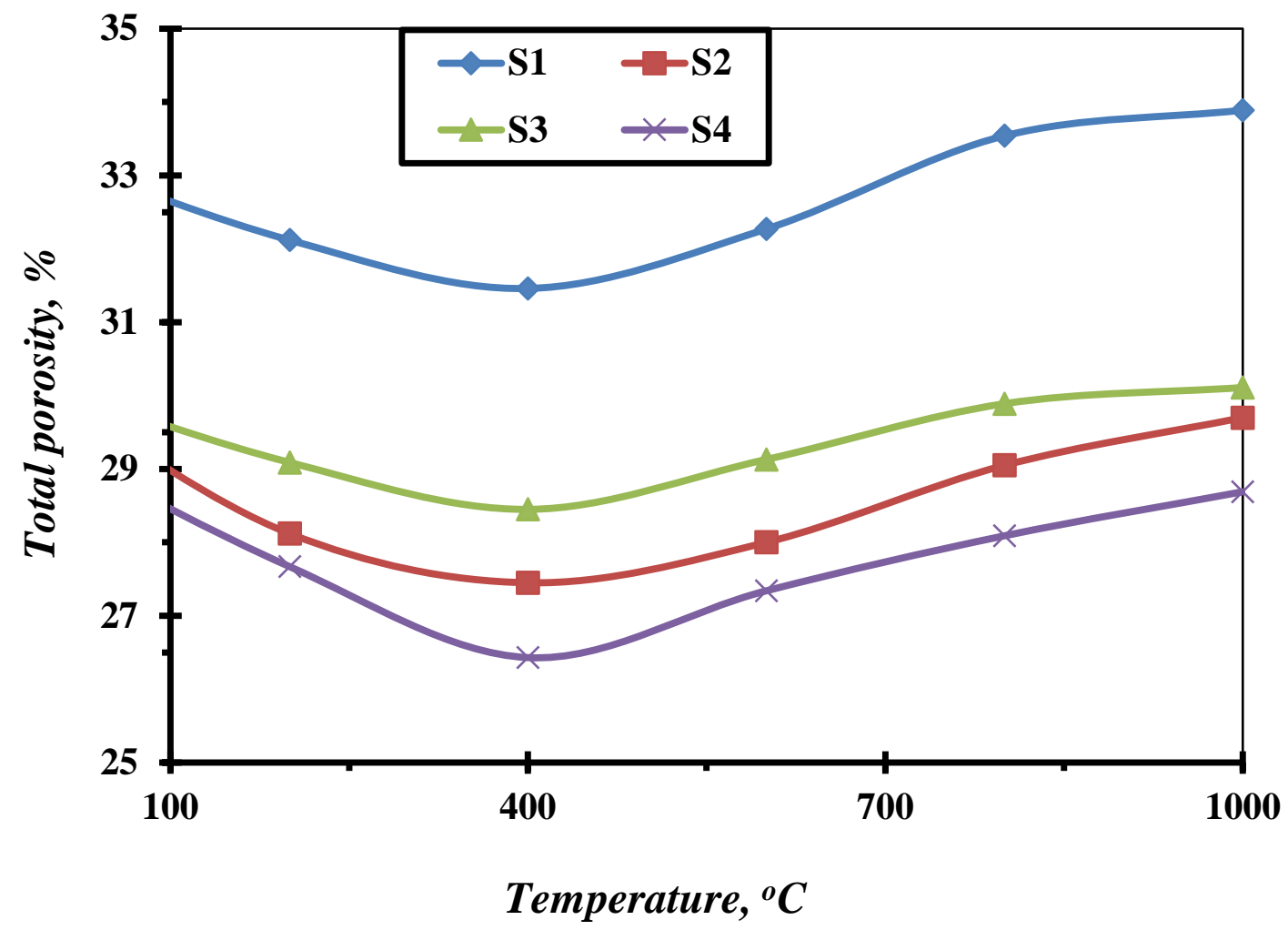

Fig. 8, B: Total porosity values of alkaline activated mixes at various firing temperatures upto $1000^{\circ} \mathrm{C}$.

\subsubsection{Weight loss:}

The weight loss values of alkali activated GBFS mixes exposed to different temperatures at 200, 400,600, 800 and $1000{ }^{\circ} \mathrm{C}$ are plotted in Fig. (9).The weight losses of the specimens are determined by measuring the mass losses of the samples after and before the exposure to treated temperature. It is found that the weight losses of the specimens reduced with elevated temperature upto $600^{\circ} \mathrm{C}$, due to deterioration the internal structure of the samples and the evaporation of free water [28]. Almost very slight reduction in the weight of the specimen is appeared with the further increased in the temperature from $800^{\circ} \mathrm{C}$ to $1000^{\circ} \mathrm{C}$.

The weight losses of the geopolymers cured at low temperature $\left(25^{\circ} \mathrm{C}\right)$, are greater than the weight losses of the samples cured at high temperatures $\left(65^{\circ} \mathrm{C}\right)$ [29]. The weight loss of the $\mathrm{S} 1 \mathrm{mix}$ when exposed to $1000^{\circ} \mathrm{C}$ was $29.64 \%$, whereas the weight loss of S4 was $27.06 \%$. 


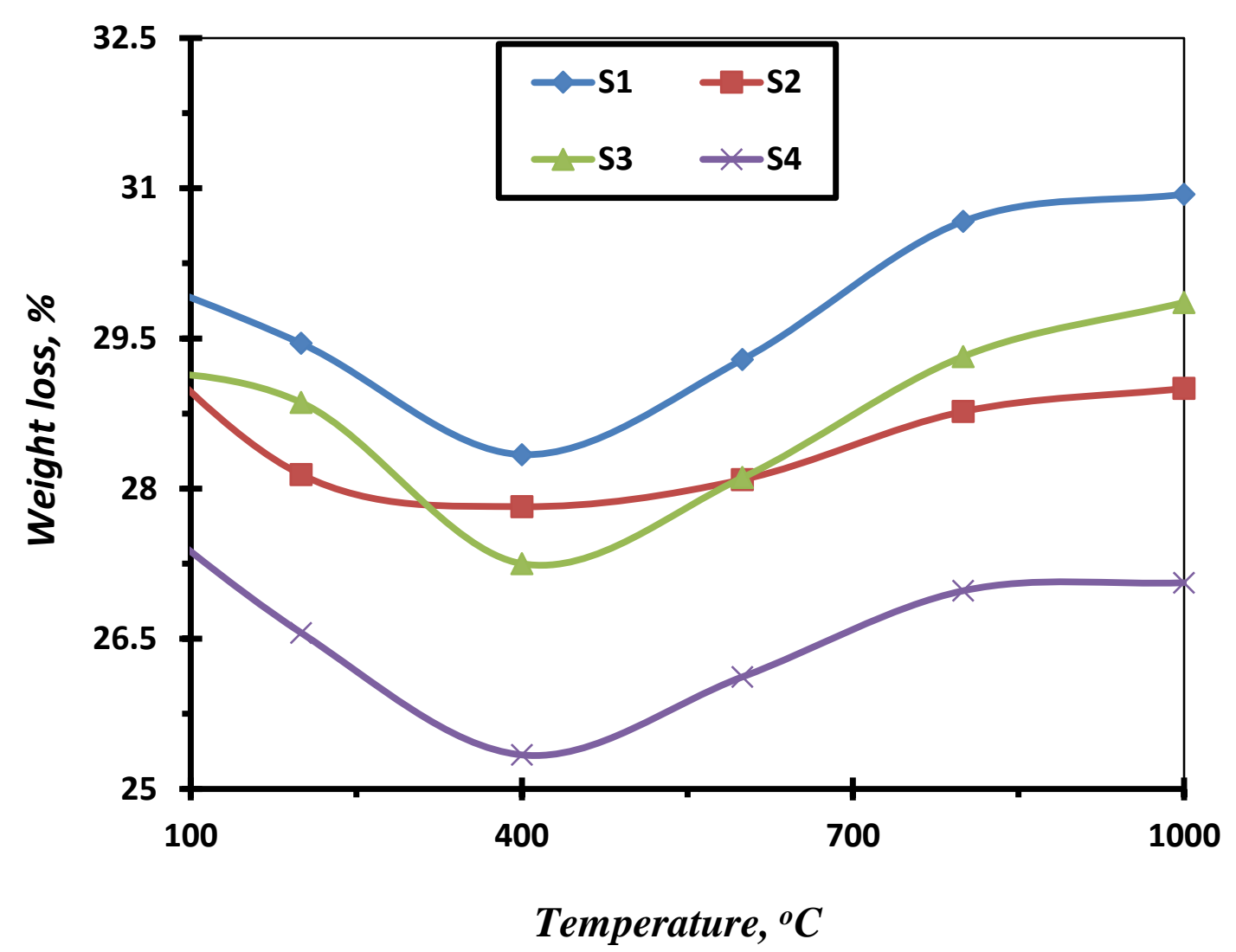

Fig. 9: Weight losses values of all mixes at various firing temperature upto $1000{ }^{\circ} \mathrm{C}$.

\subsubsection{The XRD diffraction patterns:}

Figure. (10, A-D) shows XRD patterns of AASGB binders of mixes S1. S2, $\mathrm{S} 3$ and S4 exposed to different elevated temperature; $200,600,800^{\circ} \mathrm{C}$, respectively. The XRD diffractogram of GBFS geopolymers showed the presence of various crystalline phases like (calcium silicate hydrated, quartz, mullite, maghemite, and lamite phases). XRD confirmed that the CS values of all mixes resist the elevated temperature up to $400^{\circ} \mathrm{C}$ followed by sharp decrease at 600 . The XRD patterns of all mixes at $200^{\circ} \mathrm{C}$ shows an amorphous $\mathrm{CSH}$ phase which responsible for the increasing of the CS, due to the production of alumina-silicate networks through the geopolymerisation steps in binders containing high $\mathrm{Na}_{2} \mathrm{O}$ concentration $(1 \mathrm{~mol} / \mathrm{kg}$ of binders) [30]. Furthermore, as the concentration of $\mathrm{Na}_{2} \mathrm{O}$ increased, sodium ion increased in solution that balanced more alumina-silicate network leading to formation of more crystalline phases. A sharp decrease in CS at 600 observed due to the decomposition of the CASH and CSH phases. 

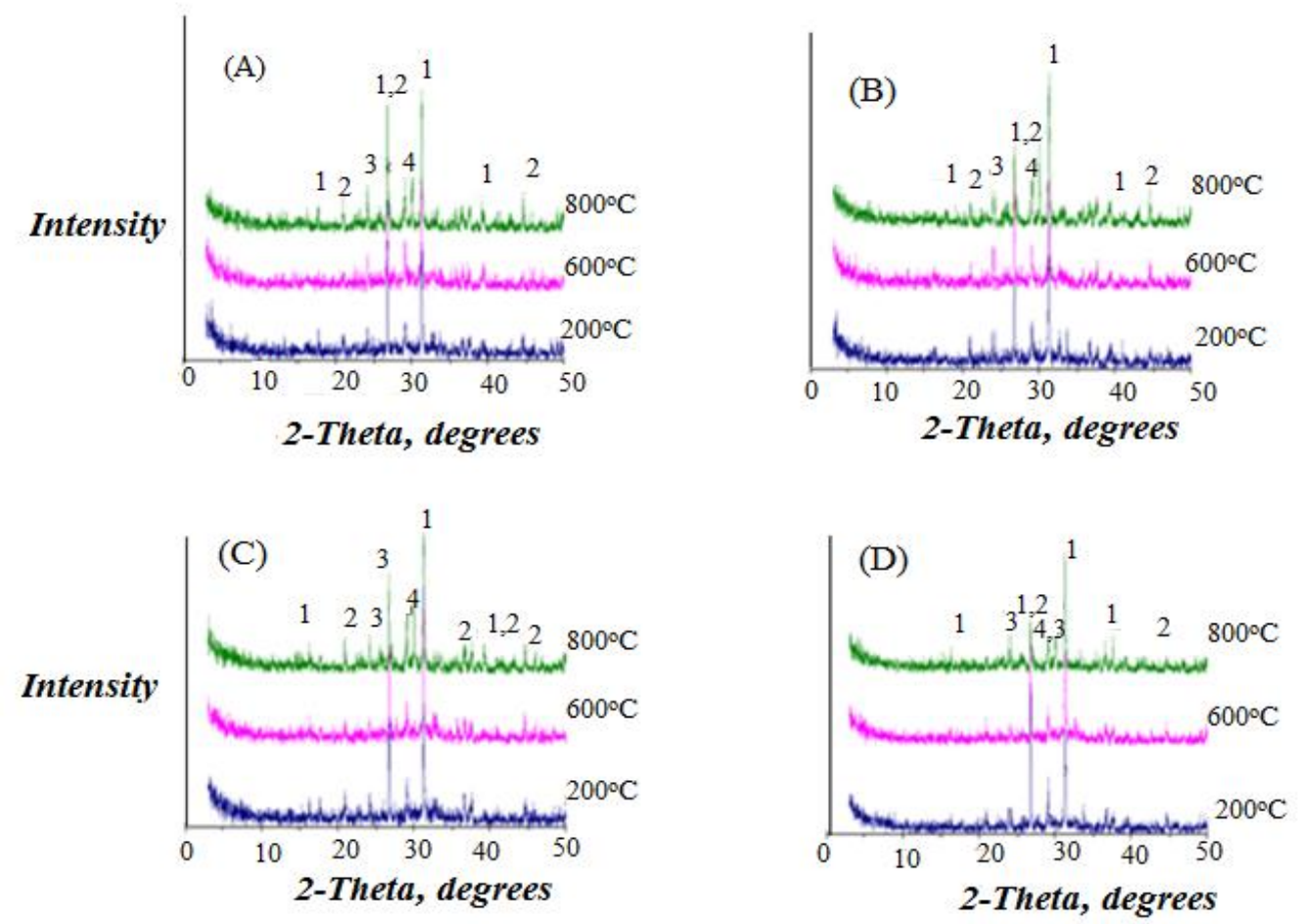

Fig. (10, A-D): XRD diffractograms of alkali activated slag $A=(S 1), B=(S 2), C=(S 3)$, $\mathrm{D}=(\mathrm{S} 4)$ at different elevated temperatures at, $200,600,800{ }^{\circ} \mathrm{C} ; 1=$ mullite; $2=$ quartz; 3= gehlenite; 4= Calcium silicate hydrate (CSH).

\subsection{Resistance to sulphate and chloride ion attack:}

\subsubsection{Magnesium sulphate solution:}

\subsubsection{Compressive strength:}

The CS values of OPC and AAGSB mixes containing 0.5 and $1 \mathrm{~mol} / \mathrm{kg} \mathrm{Na} \mathrm{Na}_{2} \mathrm{O}$ immersed in 5\% magnesium sulphate solution up to 9 months are represented in Figure. (11). Data showed that the CS values of AAGSB enhanced with the curing period as the geopolymerization progresses up to 9 months. AAGSB enhances the resistance to chemical attack, this is attributed to continuous activation of GBFS producing $\mathrm{CSH},(\mathrm{N}, \mathrm{C}) \mathrm{ASH}$ and $\mathrm{CAH}$ geopolymer gel. On the contrary the CS of OPC paste enhances up to 3 months then reduces up to 9 months [29].The reduce in the CS of OPC paste after 3 months, due to the existing of more amount of belite and alite phases that liberated $\mathrm{Ca}(\mathrm{OH})_{2}$. portlandite reacts with $\mathrm{MgSO}_{4}$ producing $\mathrm{MgOH}_{2}$ (brucite) and $\mathrm{CaSO}_{4}$ (gypsum). The formed gypsum combines with $\mathrm{C} 3 \mathrm{~A}$ and produced tri -sulphatealuminat hydrate (AFt) which causes expanding and softening 
of the concrete, meanwhile the formation of AFt in the AAGSB was not observed $[22,10]$. It is also observed that the CS values are improved with increasing the alkali concentration as showed by [31,32]. Mix S4 has a higher value of the compressive strength than neat OPC and other mixes.

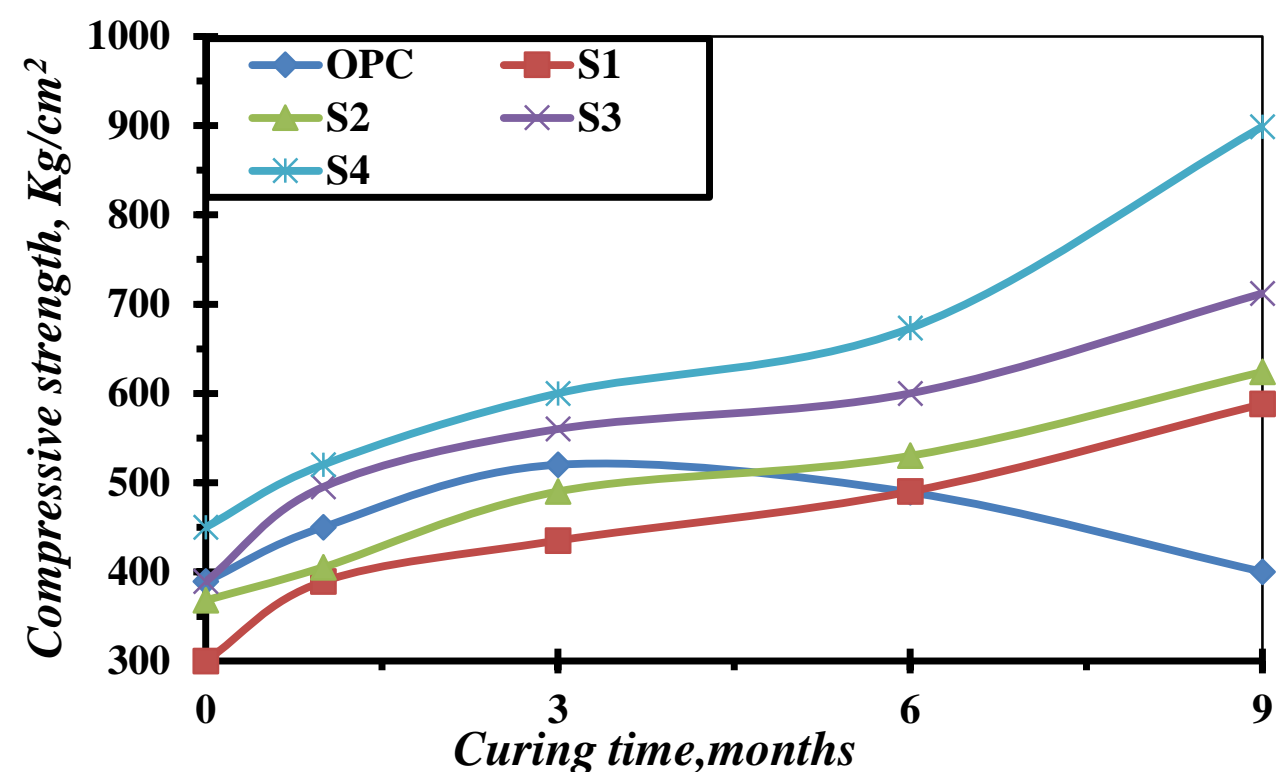

Fig. 11: Compressive strength of OPC and AASGB exposedto 5\% $\mathrm{MgSO}_{4}$ solution up to 9 months.

\subsubsection{Bulk density and total porosity:}

Changes in the values of BD and TP of OPC and AAGSB mixes including 0.5 and $1 \mathrm{~mol} / \mathrm{kgNa}_{2} \mathrm{O}$ subjected to $5 \% \mathrm{MgSO}_{4}$ solution upto 9 months are given in Figure. (12, A \& B). The BD of OPC pastes improved upto 3 months, then reduced upto 9 months. The decreases in the BD after 3 months were observed due the influence of aggressive attack of sulphate ions exposed to cement phases. On the other side, the BD of AASGB mixes increased with curing period up to 9 months and with alkaline activator up to $1 \mathrm{~mol} / \mathrm{kg}$. This is due to the continuous polymerization process, which contributes to the creation of more hydrated materials, rendering the microstructure more compact and homogeneous, raising the BD and decreasing the TP. the BD values are enhanced and the TP decreased by increasing the alkali concentration. Mix S4 has a higher value of the BD and lower value of the TP than neat OPC and other mixes. 


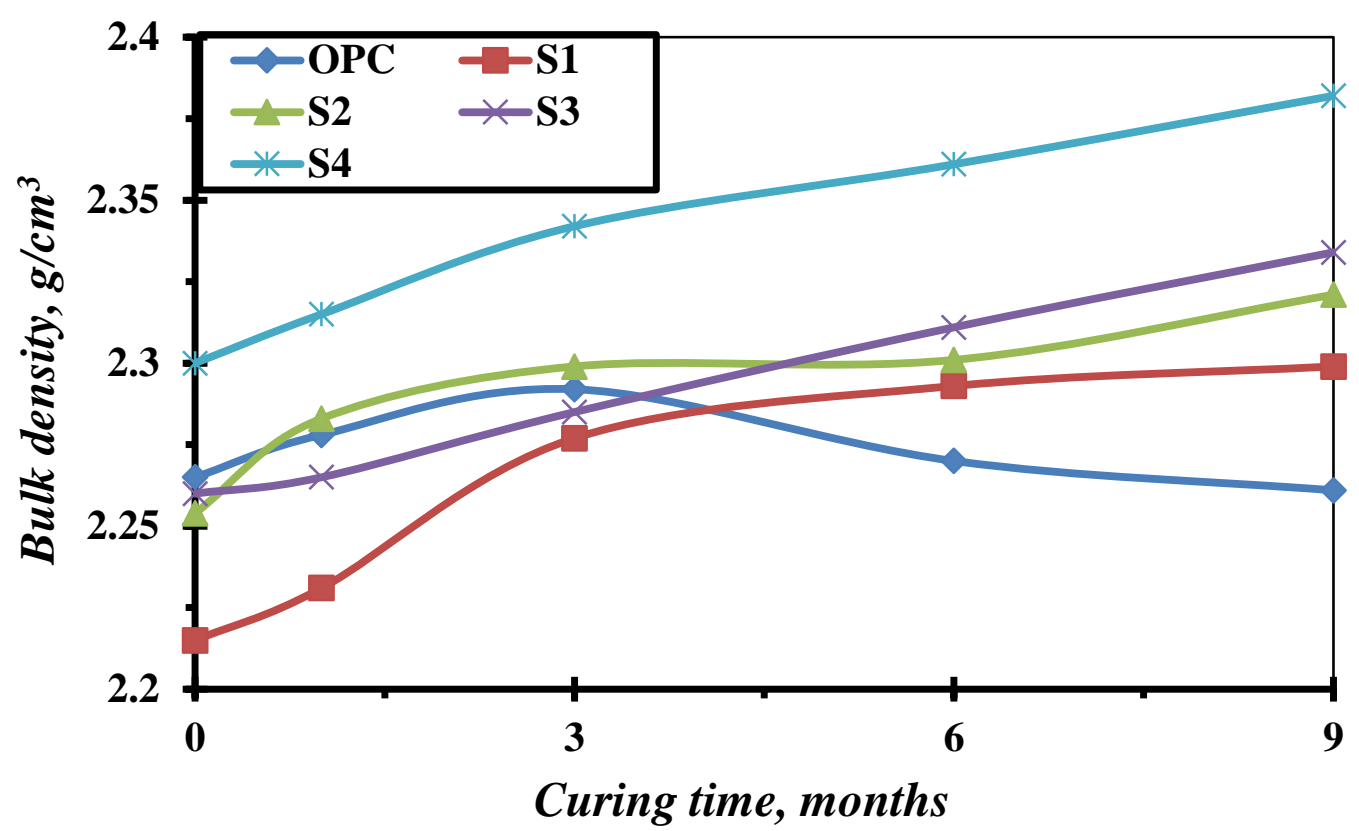

Fig. 12, A: Bulk density of OPC and AAGSB subjected to $5 \% \mathrm{MgSO}_{4}$ solution upto 9 months.

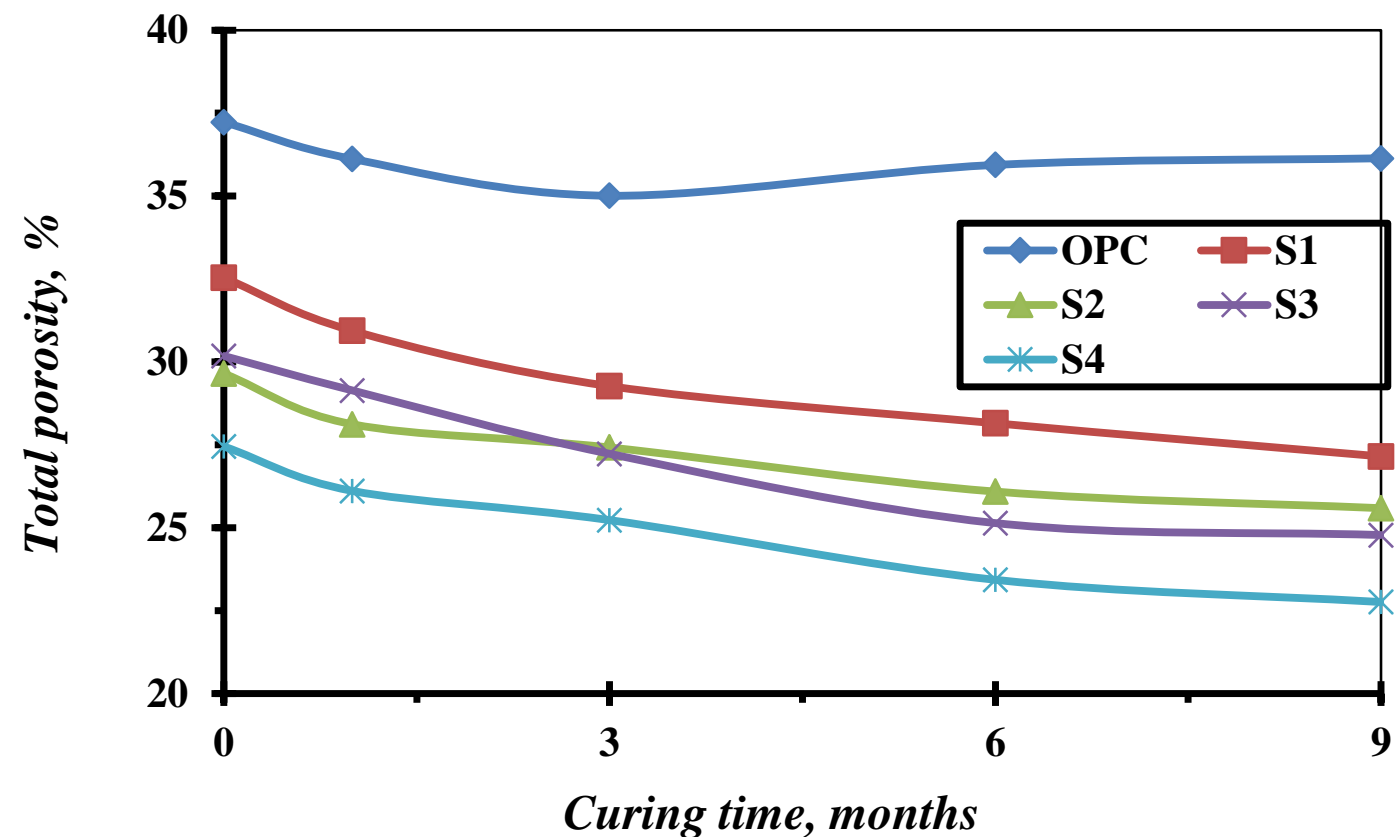

Fig. 12, B: Total porosity of OPC and AAGSB immersed in 5\% $\mathrm{MgSO}_{4}$ solution up to 9 months.

\subsubsection{Chemically combined water contents:}

The combined water content of OPC and AASGB activated by 0.5 and 1 $\mathrm{mol} / \mathrm{kg} \mathrm{Na} \mathrm{Na}_{2} \mathrm{O}$ immersed in $5 \%$ magnesium sulphate solution up to 9 months are given in Figure. (13).Chemically combined water content improved with curing period upto 
9 months for all mixtures owing to the advancement of geopolymer processes. Generally, chemically combined water content is increased dramatically up to 1 month due to the acceleration impact of $\mathrm{MgSO}_{4}$ on the pastes [7]. Chemically combined water of alkali-activated binder improved with alkali content up to 1 $\mathrm{mol} / \mathrm{kg}$. By increasing alkaline activator concentration, AASGB hydration improved by increasing GBFS dissolution rate to form polymeric gel goods.

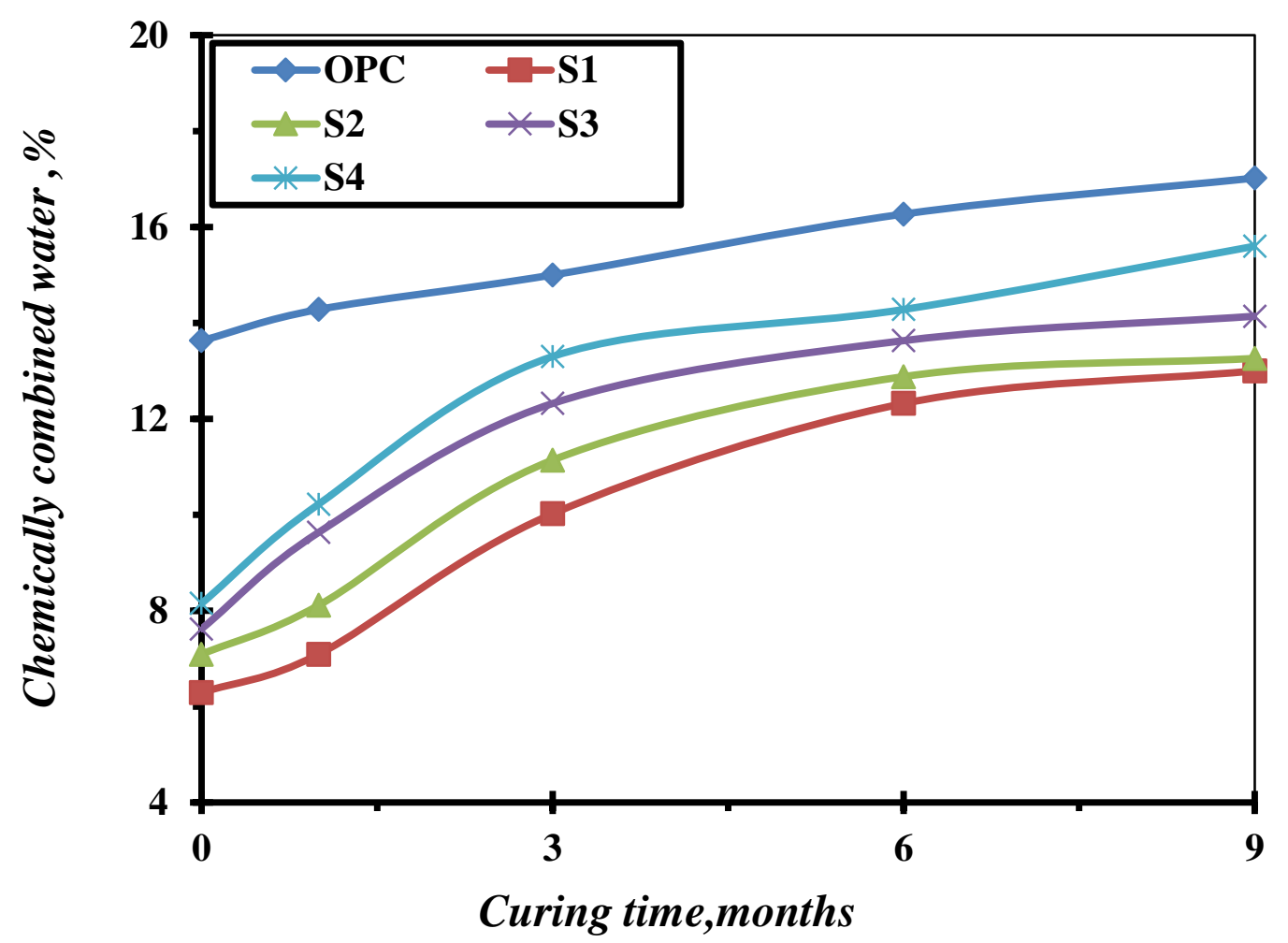

Fig. 13: Chemically combined water contents of OPC and alkali activated GBFS binder subjected to $5 \% \mathrm{MgSO}_{4}$ solution up to 9 months.

\subsubsection{Total sulphate contents:}

The total sulphate contents of OPC and AAGSB immersed in 5\% magnesium sulphate solution up to 9 months are given in Figure . (14). The results showed that the total sulphate content is increased upto 9 months for all AAGSB. OPC pastes give a higher values of the total sulphate contents than other mixes, due to a higher content of portlandite liberated in OPC paste. The data also represented that the total sulphate contents of AAGSB reduces as a result of synergetic action of thermally treated temperatures and effect of increase the alkaline activaror.S4 mix represented the 
lowest values of total sulphate content upto 9 months, this is attributed to the reduce of the penetration of $\mathrm{SO}_{4}{ }^{2-}$ anion into pore system.

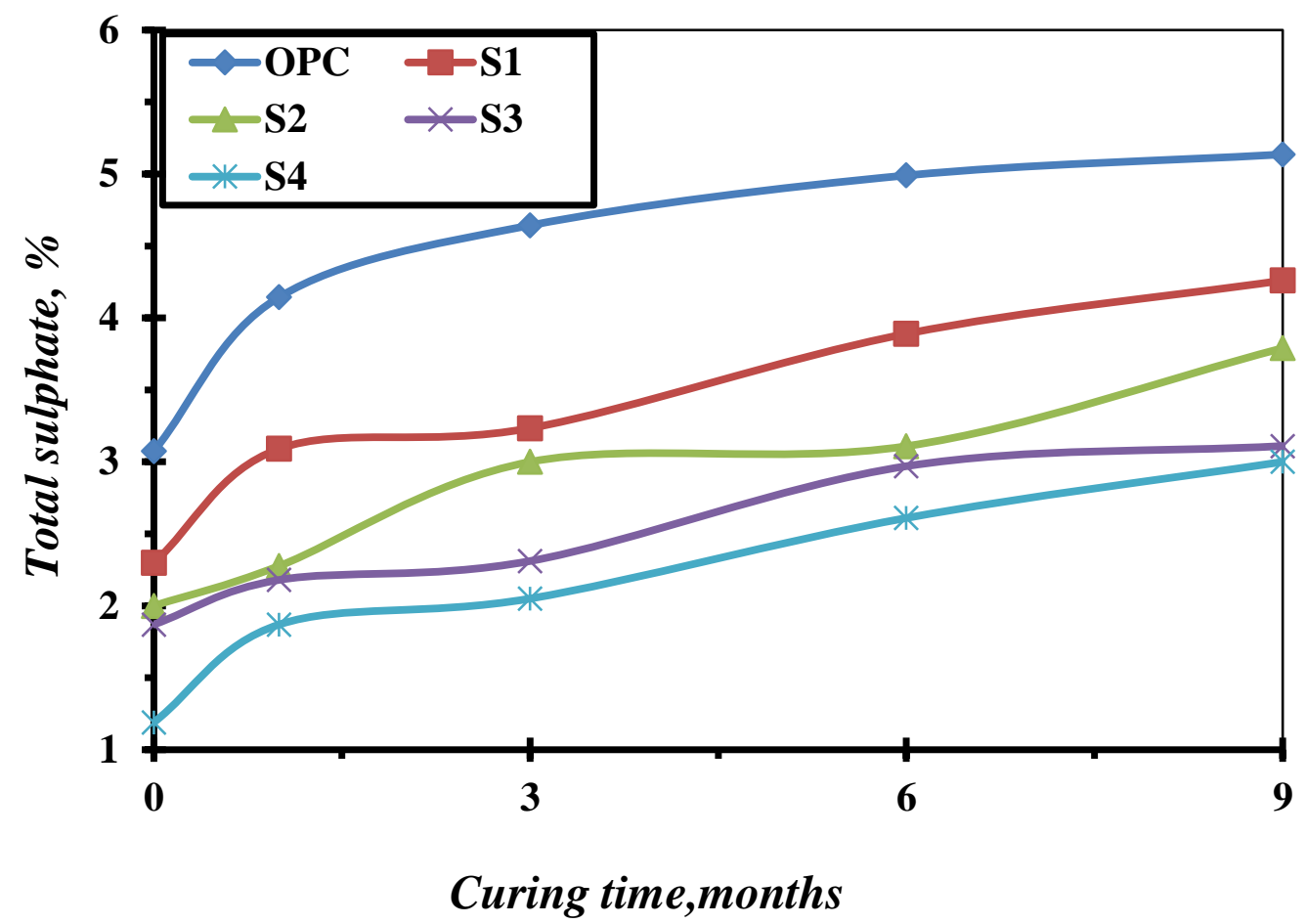

Fig. 14: Total sulphate contents of OPC and AASGB exposed to $5 \% \mathrm{MgSO}_{4}$ solution upto 9 months.

\subsubsection{Magnesium chloride solution:}

\subsubsection{Compressive strength:}

The CS values of OPC and AAGSB mixes containing 0.5 and $1 \mathrm{~mol} / \mathrm{kgNa}_{2} \mathrm{O}$ subjected to $5 \% \mathrm{MgCl}_{2}$ solution up to 9 months are given in Figure. (15). Results of the CS of the AAGSB enhanced with immersion time up to 9 months, attributed to the acceleration of hydration products with period time, due to the incorruption and adsorption of a part of $\mathrm{Mg}^{+2}$ ions on to the particles of CSH which enhance the crystallization of $\mathrm{CSH}$. The data showed that $\mathrm{S} 4$ mix represented the higher durability to the penetration of the chloride ions attack, leading to formation of a denser structure and enhances the durability to chloride medium up to 9 months. Whereas the CS values of OPC showed a lower values from 3 months upto 9 months, this is attributed to the production of Friedel's salt (chloro-aluminate hydrate) phase which causes a softening of concrete, so that the CS is reduced [15]. 


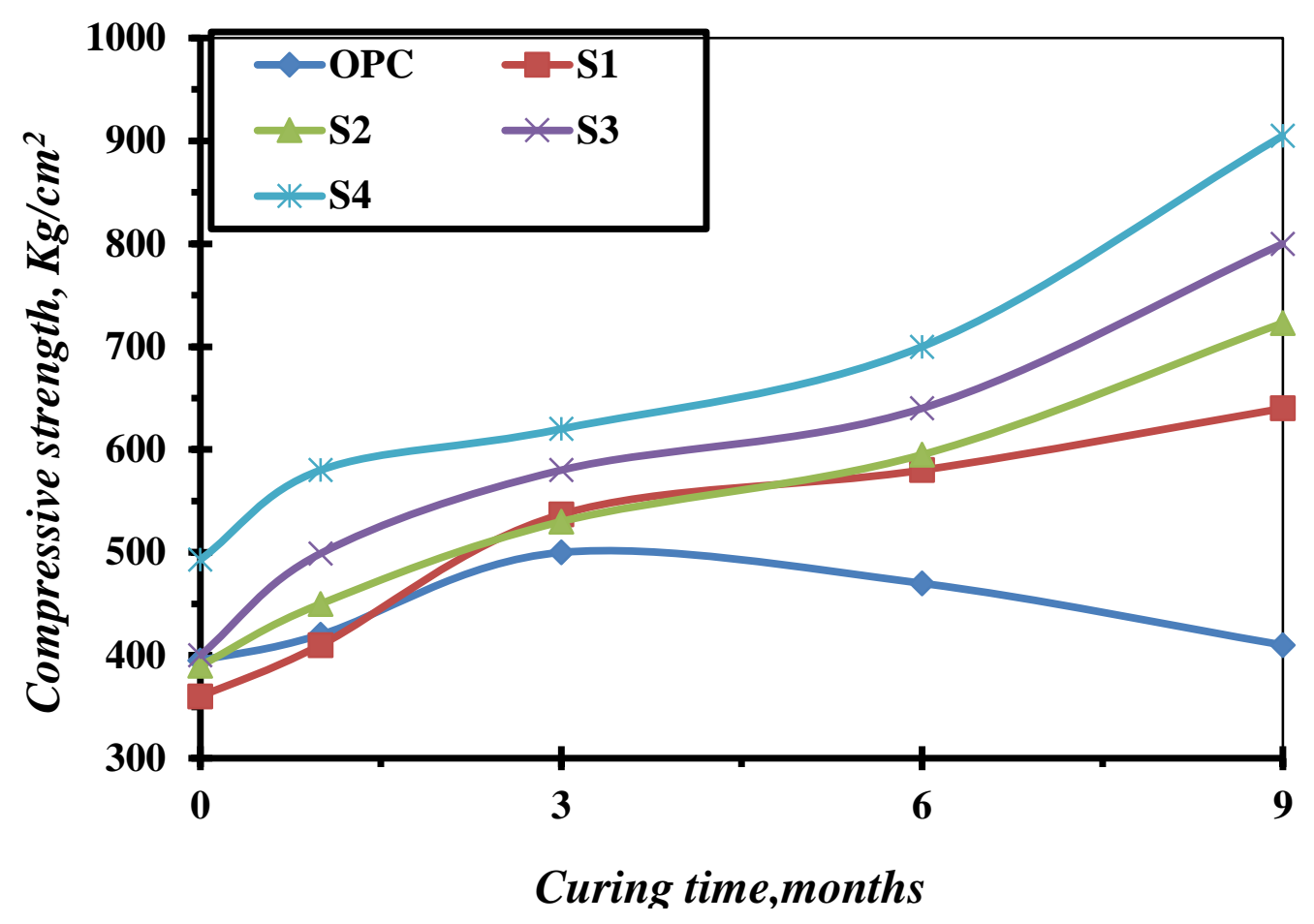

Fig. 15: Compressive strength of OPC and AASGB exposed to $5 \% \mathrm{MgCl}_{2}$ solution up to 9 months.

\subsubsection{Total chloride content:}

The total chloride contents (TC) of AASGB and OPC pastes suspended in $5 \%$ $\mathrm{MgCl}_{2}$ solution upto 9 months are given in Figure. (16). Data showed that the OPC pastes result the higher contents of TC than those of AASGB, attributed to liberation of $\mathrm{CH}$ as a result of the hydration of OPC phases which reacted with $\mathrm{Cl}^{-}$ions producing $\mathrm{CaCl}_{2}$. The $\mathrm{CaCl}_{2}$ reacts $3 \mathrm{CaO} \cdot \mathrm{Al}_{2} \mathrm{O}_{3}$ to produce chloro-aluminate hydrate $\left(\mathrm{C}_{3} \mathrm{ACaCl}_{2} 10 \mathrm{H}_{2} \mathrm{O}\right)$. In the other side, the AASG binders are not produced $\mathrm{C}_{3} \mathrm{ACaCl}_{2} 10 \mathrm{H}_{2} \mathrm{O}$. AASGB forms CSH, (N,C)ASH geopolymer gel which fills the empty pores. Then they decrease the $\mathrm{Cl}^{-}$ions penetration within the binder matrix. The radius of chloride anion is small. It can easily penetrate through the hole of pores producing $\mathrm{C}_{3} \mathrm{~A} \cdot \mathrm{CaCl}_{2} 10 \mathrm{H}_{2} \mathrm{O}$, which increases of the softening of binders [10]. 


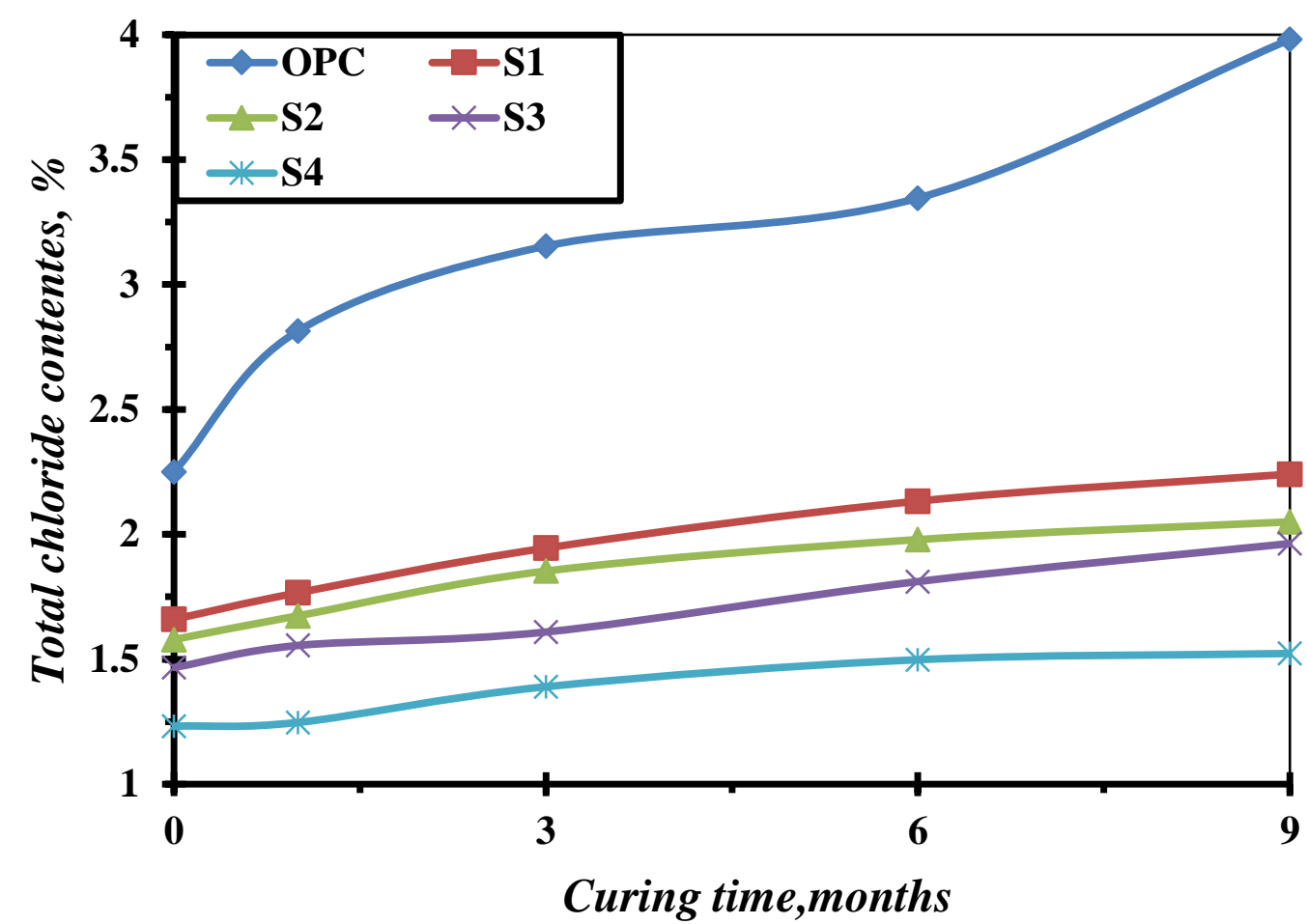

Fig. 16: Total chloride contents of OPC and alkali activated GBFS treated in 5\% $\mathrm{MgCl}_{2}$ solution up to 9 months.

\section{Conclusions}

\section{It may be concluded that:}

1. The compressive strength of the AAGSB enhanced by thermally treated temperature, and synergetic effect of the alkali contents.

2. Mix S4 is the optimum mix composition, which showed a higher CS value than other mixes at all curing period up to 180 days as well as showed the higher resistance to penetration of chloride and sulphate ions .

3. The combined slag values and $\mathrm{Wn}$ contents of the mixes cured at $65{ }^{\circ} \mathrm{C}$ (mixes S2 and S4) are higher than the mixes cured at $25^{\circ} \mathrm{C}$.

4. Compressive strength of all specimens enhanced by increasing the elevated treatment temperatures to $400^{\circ} \mathrm{C}$ but when the samples exposure to heating temperature at $600{ }^{\circ} \mathrm{C}$ has caused the further strength degradation. On the other hand, increase of the thermally treated temperatures after the material had been heated upto 800 and $1000^{\circ} \mathrm{C}$, an increase in CS was shown due to the formation of ceramic bonds. 
5. It can be concluded the mix S4 represent a good durable mix, which increases the compressive strength in both $\mathrm{MgCl}_{2}$ and $\mathrm{MgSO}_{4}$ attack solutions.

\section{References:}

[1] J.S.J. Van Deventer, J.L. Provis, P. Duxson, and D.G. Brice, "Chemical research and climate change as drivers in the commercial adoption of alkali-activated materials". Waste Biomass Valoriz: (2010) 145-155.

[2] G.H.C. Sonafrank, "Investigating 21 st Century Cement Production in Interior Alaska Using Alaskan Resources. Director. Fairbanks, AK 99708: (2010) 907-457.

[3] S. Alehyen, M. Achouri, and M. Taibi, "Characterization, microstructure and properties of fly ash-based geopolymer", Journal of Materials and Environmental Sciences, 8, (2017) 1783-1796.

[4] A. Hajimohammadi, J.L. Provis, and J.S.J. Van Deventer, "Effect of alumina release rate on the mechanism of geopolymer gel formation", Chemistry of Material, 22: (2010) 5199-5208.

[5] M. Qureshi, and S. Ghosh, S.,"Alkali-Activated Blast furnace Slag as a Green Construction Material". In proceeding of the International Conference on Advances in Engineering \& Technology, India: (2014)24-28.

[6] T. Li, Y. Zhang, and J. Dai, "Properties of Alkali Activated Slag Mortar after Exposure to Elevated Temperatures for Different Time". Proceedings of the World Congress on Civil, Structural, and Environmental Engineering, 102: (2016) 1-7.

[7] M. Abd El Aziz, S. Abd El Aleem, M. Heikal, and H. El Didamony,"Hydration and durability of sulphate-resisting and slag cement blends in Caron's Lake water", Cement and Concrete Research, 35: (2005) 1592-1600.

[8] S.N.Ghosh, S.L. Sarkar, and S. Harsh, "Progress in cement and concrete, mineral admixtures in cement and concrete. In: Moukwa M, editor. Durability of silica fume concrete", New Delhi: ABI Books; 4: (1993) 467-467.

[9] A.M. Amin, A.H. Ali, and H. El-Didamony,"Durability of some Portland cement pastes in various chloride solutions". Zem-Kalk-Gips, 50: (1997) 172177.

[10] M.A. Abd-El-Aziz , and M. Heikal, "Hydration characteristics and durability of cements containing fly ash and limestone subjected to Qaron's Lake water", Advanced Cement Research 21: (2009) 91-99.

[11] H. El-Didamony, I. Aiad, M. Heikal, and S. Al-Masry,"Impact of delayed addition time of SNF condensate on the fire resistance and durability of SRCSF composite cement pastes", Construction and Building Materials, 50: (2014) 281-290.

[12] H. El-Didamony, I. Aiad, M. Heikal, and S. Al-Masry"Effect of delaying addition time of synthesized SSPF condensate on the durability of sulphate resisting cement pastes incorporating micro-silica", Construction and Building Materials, 48: (2013) 1092-1103.

[13] H. El-Didamony, M. Heikal, and S. Al-Masry, "Effect of delaying addition time of SMF superplasticizer on the physic-mechanical properties and durability of cement pastes". Construction and Building Materials, 35: (2012) 261-269. 
[14] A. Fernandez-Jimenez, F. Puertas, I. Sorbrados, and J. Sanz, "Structure of calcium silicate hydrates formed in alkaline activated slag. Influence of the type of alkaline activator". Journal of Ceramic Society, 86: (2003) 1389-1394.

[15] F. Puertas, A. Fernandez-Jimenez, and M.T. Blanco-Varela, "Pore solution in alkali activated slag cement pastes. Relation to the composition and structure of calcium silicate hydrate". Cement and Concrete Research, 34: (2004) 139-148.

[16] F. Puertas, R. Gutierrez, A. Fernandez-Jimenez, S. Delvasto, and J. Maldonado, "Alkaline cement mortars, chemical resistance to sulphate and seawater attack". Construction and Building Materials, 52: ( 2002) 55-71.

[17] J.I. Escalante-Garcia, A.F Fuentes, A. Gorokovsky, P.E. Fraire-Luna, and G. MendozaSuarez, "Hydration products and reactivity of blast-furnace slag activated by various alkalis",Journal of Ceramic Society, 12: (2003) 2148-2153.

[18] T. Bakharev, J.G. Sanjayan, and Y.B. Cheng,"Sulfate attack on alkali-activated slag concrete", Construction and Building Materials, 32: (2002) 211-216.

[19] T. Bakharev, J.G. Sanjayan, and Y.B. Cheng, "Resistance of alkali-activated slag concrete to acid attack", Cement and Concrete Research, 33: (2003) pp. 1607-1611.

[20] M.A. Abd-El Aziz, M. Heikal, and S. Abd El Aleem, "Physico-chemical and mechanical characteristics of pozzolanic cement pastes and mortars hydrated at different curing temperatures",Construction and Building Material, 26: (2012) 310-316.

[21] ASTM Desigantion: C-150, "Standard Test method for compressive strength of hydraulic cement", ASTM Standars, (2007).

[22] M. Heikal, M.Y. Nassar, G. El-Sayed, and S.M. Ibrahim,"Physico-chemical, mechanical, microstructure and durability characteristics of alkali activated Egyptian slag". Construction and Building Materials, volume 69:(2014) 60-72.

[23] M. Heikal, M.E.A. Zaki, and S.M. Ibrahim, "Preparation, physico-mechanical characteristics and durability of eco-alkali-activated binder from blast-furnace slag, cement kiln-by-pass dust and micro-silica ternary system". Construction and Building Materials, 260: (2020).

[24] S. Aydın, and B. Baradan, "Effect of activator type and content on properties of alkali-activated slag mortars", Comp. Part B, 57: (2014) 166-172.

[25] M. Heikal, M., and S.M. Ibrahim, "Characteristics and durability of alkali activated slag-microsilica pastes subjected to sulphate and chloride ions attack". Ceramic Silikity, 59: (2015) 81-89.

[26] J.L. Provis, and J.S.J. van Deventer,. "Geopolymers. Structures, Processing, Properties and Industrial Applications". Cambridge: Woodhead Publishing,(2009).

[27] H.T. Turker, M. Balcikanli, I. Durmus, O. Erdogan, and M. Erdemir, "Microstructural alteration of alkali activated slag mortars depend on exposed high temperature level". Construction and Building Materials,volume 104: (2016) 169-180.

[28] A.G. Azevedo, K. Strecker, L.A. Barros, and L.F. Tonholo, "Effect of curing temperature, Activator solution composition and particle size in Brazilian flyash based geopolymer production." Material Research: (2018) 1-12.

[29] C.D. Atis, E.B. Görür, O. Karahan, C. Bilim, S. Ilkentapar, and E. Luga, "Very high strength (120 MPa) class F fly ash geopolymer mortar activated at different 
$\mathrm{NaOH}$ amount, heat curing temperature and heat curing duration". Construction and Building Materials.96: (2015) 673-678.

[30] F.U.A. Shaikh and V. Vimonsatit, "Compressive strength of fly ash-based geopolymer concrete at elevated temperatures". Fire and materials, 39: (2015) 174-188.

[31] A. Allahverdi, K. Mehrpour, and E.N. Kani,"Pozzolan-Based Geopolymer Cement",International Journal of Engineering Science 19: (2008) 1-5.

[32] W. Wang, H. Wang, and M. lo, "The engineering properties of alkali-activated slag pastes exposed to high temperature". Construction and Building Materials 68: (2014) 409-415. 


\section{الملخص باللغة العربية}

تاثير املاح الكبريتات والكلوريدات ودرجات الحرارة المرتفعة على خصائص خبث الحديد المصرى

محمد هيكل1، عصام كيثار2، شرين عوض33، بسمة صبحى3*

$$
\begin{aligned}
& \text { 1. قسم الكيمياء، كلية العلوم، جامعة بنها } \\
& \text { 2. قسم الكيمياءـ كلية البنات_جامعة عين شمس } \\
& \text { 3. قسم الهندسة الكيميائية، جامعة بنها }
\end{aligned}
$$

هذا البحث يهدف دراسة الخواص الكيميائية والميكانيكية والفيزيائية لمواد الجيوبوليمر (خبث الحديد المنشط

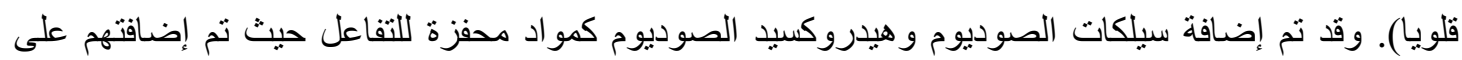
كمية ماء الخلط بنس مختلفة من التركيز ات ولذلك تم تجهيز عدد من المخاليط بكميات مختلفة من تللك المواد. وتم دراسة خواص كل خليط بعد عملية التأدرت فى الماء بعد فترات زمنية مختلفة. وقياس الكثافة الظاهرية، المسامية الكلية، ماء الخلط،الماء المتحدة كيميائى، مقاومة الضغط الميكانيكي او در اسة التركيب الدقيق باستخدام حيود الأشعة السينية. و هذه الدراسة تهدف ايضا تأثثر درجات الحرارة المرتفعة (200، 400، 600، 800 و 1000 درجة مئوية) و تأثير أملاح الكبريتات و الكلوريدات على الخلطات المختلفة.

$$
\text { ويمكن تلخيص اهم النتائج التى حصلنا عليها فيما يلى. }
$$

وضحت جميع المخاليط مقاومة ضغط ميكانيكى جيدا حنى 180 يوم و يرجع ذلك الى المحتوى القلوى

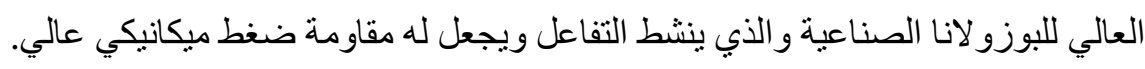
أظهر خليط خبث الأفران المنشط باستخدام 1 مول لكل كيلوجرام من هيدروكسيد الصوديوم اعلي مقاومة لأملاح الكبريتات و الكلوريدات. ولقد بينت جميع العينات زيادة فى قوة التحمل حتى 400 درجة مئوية يليها نقص فى قوة التحمل عند 600 فئ درجة مئوية وذلك النقص يرجع إلى إزالة الهيدروكلوكسى من شبكة الجيوبوليمر التى تؤدى إلى ضعف خصائصه الميكانيكية. 